\title{
Change and Continuity in the Long-distance Exchange Networks between Western/Central Anatolia, Northern Levant and Northern Mesopotamia, c.320o- $1600 \mathrm{BC}$
}

\author{
Michele Massa, Bilecik Şeyh Edebali University (corresponding author) \\ Email: michele.massa@bilecik.edu.tr \\ Bilecik Şeyh Edebali University, Faculty of Letters, Archaeology Department, Gülümbe Kampüsü, \\ Bilecik, Turkey
}

\section{Alessio Palmisano, University College London}

Email: a.palmisano@ucl.ac.uk

University College London, Institute of Archaeology, Gordon Square 31-34, WC1H 0PY, London, UK

\begin{abstract}
This paper investigates and offers explanations for the distribution of specific products (ivory and lapis lazuli artefacts, "Syrian" bottles) and technologies (metrology) that have often been invoked as tracers of long-distance trade contacts and/or political units in Anatolia, northern Levant and northern Mesopotamia during the Early and Middle Bronze Ages. Unlike former studies investigating third and second millennia exchange networks as separate entities, we examine comparatively and systematically a large corpus of published archaeological data by adopting a quantitative and spatial approach. Through this analysis, we propose that a significant degree of similarity in the shape, infrastructure and motivations behind the development and maintenance of these long-distance exchanges existed between the third and early second millennia BC.
\end{abstract}

Keywords: Early Bronze Age, Middle Bronze Age, Near East, Anatolia, Mesopotamia, Levant, Material culture, Long-distance trade, Exchange networks, Spatial approaches

\section{Introduction}

For more than half a century, long-distance and large-scale exchange networks in the ancient Near East have provided a stage for rival theoretical frameworks and academic narratives (cf. Algaze 1993; Cohen 1969 and 1971; Cusick 1998; Stein 2008; Wallerstein 1974). Different authors have interpreted evidence for the movement of products, raw materials and technologies in various contexts and periods variably as down-the-line exchange (Renfrew 1975), profit-driven trade (Dalley 2002; Larsen 1976 and 1987; Lamberg-Karlowsky 1972), gift exchange via diplomacy (Feldman 2006, 13-14; Kuhrt 1995), colonization (Gosden 2004; Rowlands 1998, 226; Stein 2005, 150; Stein 2008), raiding, or outright military conquest (Oded 1992; Stein 2005, 154). In this context, the Old Assyrian trade network established between Assur and central Anatolian polities in the early second millennium BC provides one of the most extensively documented contexts to understand the mechanisms and underlying motivations of pre-modern trade (see Barjamovic 2008 and 2011; Barjamovic et al. 2012; 
Dercksen 2001 and 2004; Larsen 1976 and 2015; Veenhof 1972; Veenhof and Eidem 2008). The arrival of Mesopotamian and Levantine traders in Anatolia, accompanied by complex administrative practices, writing, and organized religion, has often been interpreted as a pivotal moment in the history of ancient Turkey, a period when the area started integrating within the Near Eastern world after millennia of relative isolation. However, while it is undeniable that the so-called Old Assyrian Trade period (OAT, ca. 1970-1700 BC) marks the intensification of interregional contacts, there is growing evidence that it represents only the mature stage of a process that began much earlier. In particular, the last decade has seen an increasing interest in this pre-OAT phase of the interregional exchange networks, documented by a range of Mesopotamian and Levantine-originated or inspired luxury products and technologies reaching central and western Anatolia during the third millennium BC (Efe 2007; Genz 2003; Jablonka 2014; Massa 2016, 218-238; Rahmstorf 2006b and 2010; Şahoğlu 2005; Tonussi 2007; see also Özgüç 1963 and 1986b for early appraisals).

So far, however, the third and early second millennia exchange networks have been investigated largely as separate entities despite suggestions that they are intimately related (cf. Aubet 2013, 267363; Bachhuber 2012; Barjamovic 2011, 2; Larsen 2015; Şahoğlu 2005, 355; Tonussi 2007, 26-29, 365-368). Among the reasons that have so far discouraged a comparative approach is the difficulty in co-assessing datasets of largely different nature. For the a-literate Early Bronze Age (EBA) Anatolia, archaeological evidence is the only available source of information. ${ }^{1}$ On the other hand, the sketching of the complex picture of economic, political, and cultural exchanges between Anatolians and foreign merchants during the Middle Bronze Age (MBA) has so far relied almost entirely on textual analysis. ${ }^{2}$ Indeed, with some notable exceptions, excavations targeting Anatolian MBA centres have focused on the investigation of their public sectors and particularly the retrieval of written archives, often with a disregard for the archaeological context of their findings. These broadly different analytical approaches to the same phenomenon also resulted in the creation of two largely separated academic networks, one mostly composed of archaeologists, the other by philologists, circles that have until recently experienced little scientific interaction (cf. however Atıc1 et al. 2014; Kulakoğlu and Barjamovic 2017; Kulakoğlu and Kangal 2010; Kulakoğlu and Michel 2015). ${ }^{3}$

The main aim of this article is therefore to explore systematically the connection between the EBA and MBA interregional networks reaching Anatolia, trying for the first time in some analytical detail to combine a variety of archaeological evidence in order to understand changes and continuity in the shape and nature of exchange patterns between the third and the early second millennia BC. It will do so by looking in detail at a range of products (ivory and lapis lazuli artefacts, "Syrian" bottles) and technologies (metrology) as possible markers of exchange between western/central Anatolia and regions to the south-east (northern Mesopotamia and northern Levant). By using published data framed into a spatial approach, for each type of material culture we will a) assess the manufacturing place of products, b) define the mechanisms of circulation of commodities and technologies both spatially and diachronically, and c) address to which extent the spatial distributions of these artefacts are related to one or more trade circuits. Although we are using a limited number of classes of artefacts, we argue that different patterns of exchange and cultural transmission can be diachronically traced not only locally, but also at an interregional scale. Therefore, our approach is broadly

\footnotetext{
${ }^{1}$ A possible exception is represented by several references to a kingdom called kà-ni-šu in the Ebla's archives (a possible reference to Kültepe/Kaneš), and (much later) Mesopotamian literary sources that mention military expeditions of Sargon and Naram-Sin in central Anatolia (cf. Bachhuber 2012, 502-504 for a critical review).

${ }^{2}$ At present, Palmisano 2015 is the only systematic attempt to employ different classes of material culture to contextualize the OAT phenomenon within an archaeological framework. However, see Barjamovic (2011) and Palmisano and Altaweel (2015) for the employment of excavation and survey data in sketching the political geography of early second millennium $\mathrm{BC}$ central Anatolia.

${ }^{3}$ A series of biennial meetings known as "Kültepe International Meeting (KIM)" have been occurring since 2013 with the aim of promoting interdisciplinary collaboration among specialists (e.g. historians, archaeologists, anthropologists, palaeobotanists, geoarchaeologists, etc.) dealing with Kültepe and central Anatolia.
} 
contextual and aims at investigating what different exchange patterns and economic strategies (e.g. gifts, trade, marriage alliances, tribute, market profit, reciprocity, etc.) are responsible for the allocation and distribution of materials in the Near East from the end of the fourth to the middle of the second millennia BC.

The dataset employed for the analysis has been published separately (Massa and Palmisano in press) and is publicly available online at the UCL Discovery repository. ${ }^{4}$

\section{Geographical and chronological boundaries}

The main geographical focus of this study is western and central Anatolia, northern Mesopotamia and the northern Levant. In addition to this core area, limited reference will be provided for adjacent areas as well, since mechanisms of large-scale exchange can be fully understood only when framed into a broader scale of analysis. For this reason, Lower Mesopotamia, the Southern Levant, and the Aegean basin will be included in the data presentation, analysis and discussion whenever deemed appropriate. While, given the fuzziness of both environmental and cultural boundaries in the real word, drawing the borders of these regions is to some extent an artificial exercise, it is one that needs to be taken in order to make data presentation, analysis, and discussion clearer. Figure 1 shows our understanding of major geo-cultural regions that existed in the EBA and MBA Near East, areas to which we will refer in the course of the data presentation, analysis and discussion.

In the text, we will employ attested ancient toponyms for sites mostly known by these names in the literature (e.g. Ur, Uruk, Ebla, Kaneš), but we will instead employ modern names for those sites whose ancient name is unknown, uncertain or not as common (e.g. Acemhöyük, Tepe Gawra). With regard to this study's chronological boundaries, despite the realization that important episodes of exchange (e.g. obsidian at least since the Epipalaeolithic) and cultural/technological transmission (e.g. the spread of the "Neolithic package") already occurred in pre-EBA contexts (Baird et al. 2013; Carter et al. 2013; Horejs et al. 2015), we set the latest fourth millennium BC as the start of our investigation. This is because the available data suggest that the Anatolian EB I (ca 3200-2800 BC) marks a significant intensification of pre-existing interactions, e.g. in the range and nature of detectable products, raw materials, technologies and cultural behaviours that crossed the Taurus/AntiTaurus mountains (cf. Bachhuber 2015; Massa 2016). The lower chronological boundary is instead set at ca $1600 \mathrm{BC}$, the formal end date of the MBA in central Anatolia and the approximate start of the Old Hittite kingdom. In order to highlight the continuity between EBA and pre-EBA periods witnessed by the exchange of certain products, we decided to also collect and discuss fourth millennium BC evidence whenever deemed appropriate.

At the present state of research, the Anatolian Early and Middle Bronze Ages chronology is still fraught with a series of problems, including the lack of updated comparisons of intra-site stratigraphies and secure ceramic assemblages across the whole area (see however Sar1 2011 for western Anatolia), and the general scarcity of well-excavated and extensively published sites. These major hindrances prevent an agreed-upon, Anatolia-wide relative, and full sequence, hampering direct comparison with adjacent regions. Additionally, provenance analyses on lapis lazuli and ivory are still in their infancy and have been applied only in a very limited number of contexts (e.g. Lafrenz 2004; Law 2014; Re et al. 2011), therefore severely limiting our ability to directly pinpoint the source of a specific product. Bearing in mind all these limitations, we suggest that they can be in part overcome and neutralized by integrating the awareness of their existence into the process of data collection, analysis and interpretation of the results.

\footnotetext{
${ }^{4}$ http://dx.doi.org/10.14324/000.ds.10027581
} 
The present study will offer a synthesis of published data collected from 157 excavated sites with a known occupation between 3200 and 1600 BC (for a detailed description of the dataset see Massa and Palmisano, in press), recording the on-site occurrence of the investigated types of material culture (ivory and lapis lazuli artefacts, Syrian Bottles, and balance pan weights), their temporal position within the local stratigraphy and within the regional chronological sequences. Whenever possible, we will make use of absolute calendric dates, in order to provide an easy way of directly compare contemporary processes in different areas.

\section{Balance Weights}

\subsection{General characteristics}

Balance weights were used in various daily-life activities to measure quantities of goods with a standardized system composed of recognized units (with their multiples and fractions) that could be checked and agreed upon by both sellers and buyers (Hafford 2005, 345-346; 2012, 21). Research over the past three decades has identified different weight systems with different basic standards in use between the third and $1^{\text {st }}$ millennia BC throughout the Near East, including the Aegean $(1$ shekel $=6.71 \mathrm{~g})$, the Anatolian $(1$ shekel = $11.7 \mathrm{~g})$, the Levantine $(1$ shekel = $9.4 \mathrm{~g})$, the Mesopotamian $(1$ shekel $=8.3-5 \mathrm{~g})$ and the Syrian $(1$ shekel $=7.8 \mathrm{~g}$ ) systems (see Ascalone and Peyronel 2006; Mederos and Lamberg-Karlowski 2004; Parise 1991; Rahmstorf 2010). The Aegean, Syrian, Levantine and Anatolian systems were characterized by a common value (called the mina in some instances) of $470 \mathrm{~g}$, which could be respectively subdivided into 70, 60, 50 and 40 units. Instead, the Mesopotamian sexagesimal system was linked to a mina of $513 \mathrm{~g}$. The spatial distribution of a particular weight system of measurement and its overlap with others can provide us with clues about the coexistence and interaction of different polities and/or trade systems. Therefore, the circulation of raw materials and goods from distant areas (e.g. Indus Valley, Persian Gulf, Mesopotamia, Egypt, eastern Mediterranean, and Anatolia), within a network of long-distance commercial contacts, developed since the beginning of the third millennium BC conversion systems that enabled mutual equivalence between different weight systems and facilitated international trade and exchange (Alberti et al. 2006; Ascalone and Peyronel 2006; Hafford 2005 and 2012; Mederos and LambergKarlovsky 2004; Pakkanen 2011, Petruso 1978 and 1981; Rahmstorf 2003, 2006a, 2006b, 2010, 2011).

\subsection{Shapes and manufacture}

During the third (51.37\%) and second millennia BC (56.1\%), the most common morphology of balance weights was the sphendonoid (Tables 1 and 2). These weights were mostly made in finegrained dark stones (e.g. hematite, diorite, basalt) and normally had a rounded bi-conical shape with rounder and thinner ends or with cut ends. Other less common shapes include the sphere, the cylinder, the ovoid, and the spool. Complex shapes such as the lion and frog were absent in the third millennium BC and particularly rare in the MBA (both 0.34\%) and may have required fine artisanship and a high cost of production.

A chi-squared test (p-value <0.001) suggests that balance weights shapes have a significant association with their distribution zones (Tables 1 and 2). Nevertheless, these results are to be considered cautiously as the tables show many expected values less than 5 and as low as 1 and 0 (Tables 1 and 2). The results roughly show this patterning but they mostly rely on a patchy and 
incomplete dataset that not necessarily is large enough to be a good approximation of the real probabilities. However, it seems that the sphendonoid weights were the dominant shape and the results show that both in EBA and MBA they were distributed throughout the whole Near East (Tables 1 and 2, Figs. 2 and 3).

They were probably native to Mesopotamia, and then spread in Anatolia through an overland network connecting northern Mesopotamia with the central Anatolian plateau via the Anti-Taurus Mountains. On the other hand, the spool weights were mainly distributed in the Aegean basin since the beginning of the third millennium (Poliochni, megaron 832, level 2, ca. 2910-2670 BC) and only appeared sporadically in MBA Aegean contexts (Bobokhyan 2009; Haas-Lebegyiev and Renfrew 2013, 499; Kool 2012; Pulak 2000; Rahmstorf 2006a, 26-28). The spool shape seems a local Aegean innovation and its presence at Tarsus suggests a possible maritime route between the Aegean and Cilicia via the southern Anatolian coast during the EBA II (ca. 2600-2400 BC). The cylindrical, spherical and ovoid weights occur more than expected in the Levant both in the third and second millennium and could have been originally produced in the Levant since the early third millennium BC. In this framework, distinct morphologies such as the lion and duck-shaped weights could have been respectively adopted as official tools of the palace administration in Syria and Mesopotamia (Ascalone and Peyronel 2000, 34-35).

\subsection{Chronological and Spatial distribution}

The earliest employment of weight metrology is at present disputed; even though measures for length and volume are already attested in Late Uruk tablets (Nissen et al. 2004), the first account of the systematic weighing of objects only occurs in the Fara/Shuruppak archives, ca 2500 BC (Powell 1999). Equally, some objects from Late Uruk and Jemdet Nasr levels at Tepe Gawra and Uruk have been identified as balance weights, but their dating is problematic because they were retrieved from contexts investigated in the early $20^{\text {th }}$ century (Genz 2011: 845-846; Rahmstorf 2006b, 19). In the Levant two balance weights were found in EBA I levels at Tell Judeideh (Braidwood and Braidwood 1960, 324). In Anatolia, the earliest evidence of balance weights come from EBI levels (2900-2750 cal BC) at Çukuriçi Höyük (Horejs 2009 and 2016) and Poliochni (Bernabo' Brea 1964, 112). Given the available evidence, it seems that the balance weights appeared in western Anatolia a few hundred years earlier than in central Anatolia, a pattern likely biased by the absence of well-documented evidence for the early third millennium archaeological contexts in central Anatolia. A real problem in assessing what were the geographic areas within the different weight systems were used is represented by the fact that most EBA balance weights found in central Anatolia have been published without their own masses. A chi-squared test shows that weight systems and distribution zones (Anatolia, Levant and Mesopotamia) are significantly associated (see Table 3 and Fig. 2). In Southern Mesopotamia there are more weights than expected belonging to the Mesopotamian System. This may indicate that in Lower Mesopotamia the local weigh system was the one most commonly used (Table 3 and Fig. 4a). By contrast, in northern Mesopotamia there is a wider variety of weight systems (Table 3 and Fig. 4a), which indicates how this area was criss-crossed by long-distance commercial routes related to different trade circuits. In Anatolia, there are less than expected weights belonging to the Anatolian system and more than expected Aegean and Levantine weights. This result could be biased by the almost total lack of evidence of well-documented balance weights from central Anatolia, but may also reflect the commercial links between western Anatolia and the eastern Mediterranean communities as result of maritime contacts. In addition, the distribution of Aegean weights in the 
Levant suggests the existence of a trade circuit connecting the Aegean and the Levant via southern Anatolian coast.

In the MBA there is more documented evidence of balance weights across the Near East. In the Levant, Ebla has been the subject of a systematic and well-documented study (c.f. Ascalone and Peyronel 2006a and 2006b). Other sites such as Tell el-Ajjul and Tell el-Jeezer in Southern Levant have yielded good evidence of balance weights. Along the Middle Euphrates Valley, only Tell Munbaqa and Mari have respectively yielded four and two weights (Czichon and Werner 1998, 202, pl. 92; Parrot 1959, 80). In northern Mesopotamia balance weights $(n=54)$ have been found only at the sites of Aššur, Tell Munbaqa and Tell Bi'a (cf. Czichon and Werner 1998, 202, n.876-879; Karwiese 1990; Miglus and Strommenger 2007 29, 50; Zeyrek and Kiziltan 2005; Unger 1918). In central Anatolia evidence comes exclusively from the levels II, Ib and Ia of Kültepe's lower town (91 items; Özgüç and Özgüç 1953, Özgüç 1986a) and from Boğazköy (15 items; Bittel et al. 1957; Boehmer 1972). A chi-squared test shows that the weight systems and their distribution zones are significantly correlated. In Mesopotamia there are more weights than expected belonging to the Mesopotamian system (Table 4 and Fig. 4b). As already observed in the third millennium, the Mesopotamian weight system was mostly used in its original distribution zones. On the other hand, in Anatolia there are less than expected weights belonging to the Anatolian system and more than expected Mesopotamian weights (Table 4, Fig. 4b). This result could be biased by the fact that almost all weights from central Anatolia (91 out of 106) come from Kültepe's lower town levels II-Ib (ca. 1970-1700 BC) and may reflect the commercial activities of Assyrian merchants (Fig. 3). It is quite surprising that just six weights out of 81 from levels II and Ib of Kültepe's lower town are related to the Anatolian shekel (11.75 g). Nevertheless, that sample cannot be regarded as representative of the local population because Kültepe's lower town was inhabited by both Anatolian and Assyrian merchants. The Anatolian weight system, outside its main primary area, has been retrieved at Ebla (31 examples) and Aššur (five examples) as evidence of inter-regional contacts between northern Levant, northern Mesopotamia and Anatolia in the early second millennium BC. In all distribution zones, both Syrian and Mesopotamian weight systems are the most represented ones. Nevertheless, while in northern Mesopotamia the Anatolian and Aegean systems are underrepresented (respectively $8.7 \%$ and $7 \%$, Fig. 4b), in the Levant they are more recurrent (respectively $13.7 \%$ and $16.3 \%$, Fig. 4b). The higher frequency of Aegean and Anatolian weight systems in the Levant could be explained as the consequence of contacts between Syria, Anatolia and Levantine coast or more simply with the closeness to areas where those two kinds of weight systems were more often used. Instead, Lower Mesopotamia shows a more local use of the Mesopotamian standard (Fig. 4b), and the total lack of weights belonging to the Aegean and Anatolian standard could suggest no direct contacts between this region and the Anatolian and Aegean communities.

\section{Ivory}

\subsection{The origin of the Near Eastern ivory}

On the basis of textual, pictorial, palaeo-environmental and zooarchaeological evidence, several main habitat areas can be identified for hippopotami and elephants, the main source of worked ivory in the ancient Near East (Fig. 5). During the EBA and MBA, hippopotami lived on the Nile Delta, along the river valleys of the southern Levant and in the Orontes valley (Horwitz and Tchernov 1990; Krzyszkowska 1988, 227-228; Krzyszkowska and Morkot 2000, 326; Moorey 1994, 115, 118). There is also archaeological and textual evidence that during the Bronze and early Iron Ages elephants lived in the marshy areas of the Orontes and Amuq plains, and in the gallery forests along the Euphrates 
and major tributaries (Krzyszkowska 1988, 226-228; Moorey 1994, 116-120; Pfälzner 2013). In particular, a recent review by Canan Çakırlar and Salima İkram has suggested that elephants may have been reintroduced in the Near East after they became extinct in the Pleistocene, and that their anatomical features indicate India as the most likely origin for the 'Syrian' elephants (2016, 168-178). While the authors indicate ca $1800 \mathrm{BC}$ as the date for the re-introduction of Asian elephants in the region (likely in the context of elite hunting and ivory consumption), finds from Tell Munbaqa (Pfälzner 2013, 115) and Ras Shamra (Hooijer 1978) suggest the possibility that this may have occurred already in the late EBA (Fig. 5). Further afield, elephants are attested along the lower Nile in Nubia, as well as in the Indus valley. Nubian ivory may have been a significant source for Egyptian workshops, while Indian ivory may have been traded in Mesopotamia at least between 2500-1900 BC (Moorey 1994, 118-121).

\subsection{Ivory manufacture}

With the available evidence, the only pre-LBA ivory workshops known in the study area are from the small Ghassulian-period (mid-late $4^{\text {th }}$ millennium) hamlet of Bir es-Safadi (Barnett 1982, 23) and from the MBA palaces at Ebla (room L. 4070, Northern Palace), Alalakh (rooms 11-13, level VII) and Tell Sakka in the Levant (al-Besso 2015; Peyronel 2016, 191-195; Scandone-Matthiae 2002, and 2006; Yener 2007, 154). Ateliers attached to these palaces clearly suggest a specialized and centralized production of luxury ivory items, which precedes the flourishing ateliers of the Late Bronze Age (Peyronel 2016, 190). In the early third millennium, hippopotamus tusks found at Ay and Arad (Callaway 1972; Davis 1976) are an indirect evidence for probable in situ ivory manufacture (Fig. 6). Later on, a small tusk segment in mid-late EBA contexts at Tell Jerablus Tahtani (Emerin et al. 2015, 190) represents the earliest evidence for local production in the northern Levant, followed by five elephant tusks retrieved in the Alalakh's level VII palace during the ensuing MBA (Fig. 7; Woolley 1948, 14).

At present, there is no direct archaeological evidence for ivory manufacture in northern or southern Mesopotamia during the third and second millennia BC. However, between ca 2500-1900 BC, the local production of elephant ivory can be assumed based on both the quantity and quality of products (some clearly Mesopotamian in style), and the mention of elephant tusks' shipments (Moorey 1994, 118-121).

In the Aegean, the earliest evidence for local ivory production, a small segment of hippopotamus tusk, is found in secure EM IIa (ca 2700-2600 BC) contexts at Knossos on Crete (Fig. 6; Krzyszkowska 1988, 210). On Crete, the apogee of ivory production is, however, EM III/MM Ia (ca 2200-1950 BC), when a significant number of ivory seals and figurines had been produced across the island (Betancourt 2014, 50, 64-65, 86; Krzyszkowska 2005, 63). In particular, the seal motifs are clearly Cretan and thus prove their local manufacture (Krzyszkowska 2005, 33; Rehak and Younger 1998, 232-233). By contrast, the earliest evidence for ivory manufacture in Anatolia only dates back to the OAT period (ca 1950-1800 BC). Several elephant tusks found in Acemhöyük's burnt palace, as well as local products (inlays, figurines, seals) from Acemhöyük, Kültepe and Alacahöyük made in hippopotamus ivory, further attest to yet-unidentified Anatolian ivory workshops (Fig. 7; Bourgeois 1992, 63; Caubet 2013, 450; Caubet and Poplin 1992, 92; Özgüç 1986a, 70-71).

\subsection{Exchange and circulation of ivory products}


Together with the Nile Delta, the southern Levant represents the core area of ivory manufacture and exchange, an industry almost exclusively based on hippopotamus ivory (Fig. 5). Here, the earliest attestations date back to the mid-fourth millennium BC, as witnessed by perforated tusks, statuettes, hairpins and knife handles from Bir es-Safadi, Abu Matar, Nahal Mishmar, Nahal Qanah and Shiqmim (Rowan 2013, 231). Throughout the EBA and MBA, the Byblos ivories are among the richest assemblages in the region, often including Egyptian/Egyptianizing products that suggest import of finished artefacts and possibly raw tusks (Barnett 1982, 25; Caubet and Poplin 1992, 92). In the northern Levant, with the possible exclusion of a poorly stratified palette from Tell Judeideh (ca 4000-3300 BC, Braidwood and Braidwood 1960, 133), ivory was instead not present in detectable quantities before the mid EBA, e.g. at Umm el-Marra (Caubet and Poplin 1992; Rehak and Younger 1998; Schwartz et al. 2006, 611-618, fig.14; Schwartz et al. 2012, 163, 169-170, fig.14).

In Mesopotamia, despite several mentions of possible "ivories" from Chalcolithic contexts (Moorey 1994, 119-120), a seal from Arslantepe VII's cultic complex represents the only secure pre-EBA ivory artefact outside the elephant and hippopotami habitat areas (Caubet 2013, 450). Otherwise, ivory became fairly common from late ED III times (ca 2500-2400 BC) onwards, and often displayed quite elaborate forms, e.g. in the Ur Royal Cemetery and at Mari (Moorey 1994, 120). Even in the general scarcity of specialist assessments, both archaeological and textual evidence suggests an almost exclusive employment of elephant ivory for Mesopotamian finds (Fig. 5). While exploitation of the elephant populations living along the Euphrates seems very probable, a flourishing trade in raw and worked elephant ivory between southern Mesopotamia and the Indus valley is also well documented. An ED III text from Lagash and an Akkadian text from Girsu mention the receipt of tusks from unknown locations, while several Ur III and Isin-Larsa texts from Ur refer to raw and manufactured ivory being shipped from Meluhha or more commonly from Magan and Dilmun, i.e. from the Indian subcontinent through the Persian Gulf (Lambert 1953; Oppenheim 1954, 11, 15; Ratnagar 1981, 113, 116; Sheldon 1971, 180).

In the Aegean, other than the already-mentioned hippopotamus tusk from EM IIa Knossos, the vast majority of the pieces (at least several dozens) is found on Crete in EM III/MM Ia funerary contexts (ca 2200-1900 BC, Legarra Herrero 2014). ${ }^{5}$ Although of clear local production, many betray a familiarity with Near Eastern iconography (e.g. the "parading lions") and adapt shapes of Near Eastern seals like apes, birds and flies (Krzyszkowska 2005, 33; Rehak and Younger 1998, 232-233). Furthermore, the totality of analyzed Cretan ivory objects was produced with hippopotamus ivory (Krzyszkowska 2005, 63-64), thus suggesting a Levantine origin of the raw material. The Poliochni Yellow (ca 2300-2200 BC) stamp-cylinder is at present the only secure ivory piece from the western Anatolian seaboard (Bernabò Brea 1976, 298-302; Kenna 1970): both the shape and motif strongly suggest an eastern Mediterranean manufacture. Thirteen pieces from Troy IIg (ca 2300-200 BC), including buttons, inlays, a knife handle and two scale beams are also described as ivory but have not been studied by a specialist (Blegen et al.1951, 174, 324, 336; Schliemann 1881, 475-476). The Cyclades, mainland Greece, and inland Anatolia have so far not yielded ivory artefacts from EBA contexts (Fig. 6).

During the ensuing MBA, ivory exchange networks seem to have witnessed a radical reconfiguration. With the disruption of the trade connections with the Indus valley via the Persian Gulf, in Mesopotamia archaeological evidence for ivory becomes sparse (Fig. 7). This is also confirmed by textual sources, that no longer mention ivory throughout the Old and Middle Babylonian periods

\footnotetext{
${ }^{5}$ Legarra Herrero, in his comprehensive gazetteer of Pre-palatial and Proto-palatial Cretan burials, lists ca 350 "ivory" objects coming from funerary contexts dated between EM IIa and MM Ia (2014, 167-303). However, since most contexts have been excavated before methodologies for identification of ivory had been safely established, the number of real Cretan ivories is difficult to assess and is probably much lower (Krzyszkowska 2005, 59).
} 
(Moorey 1994, 118, 121-122; Oppenheim 1954, 11-12). In the Aegean, there also seems to be a substantial hiatus in the local manufacture of ivories as well as in the arrival of imported products, as very few artefacts have been deposited within the whole basin between ca 1900-1600 BC (Fig. 7; Krzyszkowska 2005, 70-74; Rehak and Younger 1998, 233). Only a handful of objects are known in MM II (ca 1850-1700 BC) contexts at Mallia (Poursat 1992) and a single seal from slightly later contexts at Çeşme-Bağlararası, a probable Cretan import (Şahoğlu 2012, fig.5). It is only during the MM III/LM Ia (ca 1600-1500 BC) that ivories started re-occurring on Crete and coastal Anatolia, as well as making their first appearance in mainland Greece (Krzyszkowska 2005, 119).

By contrast, central Anatolia witnessed the first appearance of raw ivory and ivory products in the area during the OAT period (Fig. 7): very elaborate artefacts are found at numerous sites including Acemhöyük, Alacahöyük, Alişar Höyük, Eskiyapar, and Kaneš (Bourgeois 1992; Caubet and Poplin 1992, 92; Krzyszkowska 1988, 230; Moorey 1994, 117; Yener 2007, 158).

Notwithstanding the scarcity of specialist assessments related to animal species and the lack of provenance analysis on raw and finished products, the spatial analysis of EBA and MBA skeletal remains, tusks and finished goods clearly delineates different patterns for hippopotamus and elephant ivory (Fig. 5). In particular, the available data indicate that the Euphrates may have acted as a breakwater for the exchange of these products since hippopotamus ivory is virtually absent east of the river. In addition to the extreme rarity of hippopotamus ivory in the archaeological record east of the Euphrates (one comb from pre-EBA Tepe Gawra and a few objects from LBA Tell Brak), this hypothesis is also supported by the virtual absence of hippopotami in Bronze Age Mesopotamian art and in written documents (Moorey 1994: 115). This recognition has two important ramifications: the first is that, in all likelihood, EBA/MBA Aegean ivory originated from coastal Levant rather than inner Syria or Mesopotamia where elephant ivory was common. The second is that the presence of hippopotamus ivory in MBA central Anatolia hints at commercial contacts with northern Levantine city-states like Ebla, as also indicated by several texts from Kaneš (Barjamovic 2011, 7-9) and confirmed by the MBA metrological evidence (see above).

\section{Syrian Bottles}

\subsection{General characteristics and definition of shapes}

Syrian Bottles are small to medium-sized ovoid, globular or oblong vessels (between 23 to $6 \mathrm{~cm}$ in height and 12 to $4 \mathrm{~cm}$ in width, with volumes between 80-1000 ml) with a small narrow neck and flaring rim that likely contained valuable liquids such as oils, perfumes, or ointments (Ay et al. 2014; Zimmermann 2005, 164). The presence of rhomboidal "net bag" designs, visible as shallow relief decoration on the surface of some bottles retrieved in Early Bronze Age occupation levels at Kaneš , provide a further clue about how these vessels may have been wrapped and carried, leading Zimmermann $(2005,164 ; 2006)$ to propose that Syrian Bottles transported their content over longdistances. Syrian bottles were originally produced in the Middle Euphrates in the EBA II period (ca. 2700-2600 BC) and then spread from the middle of the third millennium BC onwards into central and western Anatolia, and as far as the Aegean Sea, eastern Thrace and north-eastern Anatolia as imports or local imitations (Schachner and Schachner 1995, 86; Tonussi 2007, 236; Rahmstorf 2006a, 55; Zimmermann 2005, 161). Two main typologies have been identified: the globular shapes, which started in the EBA II period (ca. 2600-2400 BC) and continued to be used until the middle of the second millennium BC (, and the alabastra, which appeared during the early Akkadian period (ca. 2400-2250 BC), and disappeared at the end of the third millennium BC (Emre 1999; Kontani 2010, 
53; Kühne 1976, 37-38; Orthmann and Rova 1991, 136-142). Emre, with regard to the proportions between height and width, identifies four different sub-typologies for the early second millennium's Syrian Bottle (1999, 39-41): 1) Ovoid-egg shape; 2) Globular shape, 3) Cylindrical shape, and 4) Piriform shape.

\subsection{Origin and Manufacture}

In the past decade, several studies have analyzed the spatial distribution of Syrian Bottles in Anatolia, Levant and Mesopotamia in the third millennium BC and the possible dynamics for their longdistance exchange (Rahmstorf 2006b; Tonussi 2007; Zimmermann 2005, 2006). Nevertheless, missing from these studies is a detailed analysis of their possible origins, contextual dating and the full spectrum of finds.

Even in the scarcity of detailed pottery analyses for most of the finds, it is clear that some specimens were locally made near or at the sites where they were deposited, based on a comparative assessment of fabrics, surface treatments, production techniques and firing techniques. During the EBA, along the Euphrates and northern Syria, these bottles were always wheel-made, well-fired, thin-walled and were manufactured in a limited number of wares, broadly grouped into "Metallic Wares" (Ring Burnished, Grey Jazirah, Black Euphrates and Stone Wares) and "Simple Wares" (Brown Ware and Euphrates Banded Ware, Tonussi 2007:236-237). During the MBA, the Syrian bottles in the same area were wheel-made, well fired, made of black to dark grey paste and burnished in the same colour, and had a surface decorated with shallow horizontal incisions.

On the other hand, at several sites, the Syrian bottles are clearly made in local ware groups. This is e.g. the case of Müslumantepe in north-eastern Mesopotamia (in Nineveh V Ware, Ay et al. 2014, 126), Tarsus in Cilicia (Light Clay Ware, Goldman 1956, 154), Troy in north-western Anatolia (RedCoated and Black Polished Wares, Blegen et al. 1951, 27, 42, 50, 58; Schliemann 1881, 441, 442, 605), and Küllüoba and Kaneš in central Anatolia (Red-Slipped Wares, Özgüç 1986b, 34-38; Türkteki 2010, 170-171). Intriguingly, the local manufacture of the containers also meant in all likelihood the local manufacture of the contents, which can be regarded as the valued element in the product (cf. also Massa and Tuna, in press).

Three different scenarios can explain the spatial distribution of Syrian Bottles in Anatolia: a) direct imports from northern Syria, b) imports from other production centres located in the region, and c) production on site or immediate vicinity. Probable direct northern Mesopotamian imports are found in Cilicia, Cappadocia, and the central Anatolian plateau. Products that were likely manufactured on site or in its vicinity are attested at Kaneš, Troy and Tarsus in levels roughly contemporary with the direct imports, while bottles of probable Anatolian production are found at Palamari (Sporades) and Galabovo (eastern Thrace). Furthermore, there are several examples made of metal (gold, silver and lead) at Eskiyapar, Tarsus, and Troy, which are in all likelihood local adaptations of the form. Locally manufactured bottles display in several cases a significant degree of adaptation concerning forms, production techniques (with a few handmade pieces), fabrics/surface treatments (e.g. Red-Coated and Black Polished Wares) and materials (in EBA Anatolia several metal bottles are known).

\subsection{Distribution of Syrian Bottles}

An assessment of the diachronic distribution of Syrian Bottles provides useful insights about the extent and the intensity of long-distance contacts between Anatolia, Mesopotamia, and Levant in the Early and Middle Bronze Ages. 
Across the whole area, 64 sites have yielded Syrian bottles dated to the Early Bronze Age (Fig. 8). Thanks to the different fabric characteristics, it has been possible to understand that in the third millennium BC the furthest northern and north-western examples from Anatolia, the Aegean and eastern Thrace (Troy, Küllüoba, Galabovo and Palamari) were local productions rather than imports (Rahmstorf 2006a, 56; Schachner and Schachner 1995, 88; Zimmermann 2005, 163-164;). Instead, the westernmost area where "real" imports spread was central Anatolia (Acemhöyük and Kaneš; Schachner and Schachner 1995, 91; Kontani 2010). Unlike the Early Bronze Age, in the Middle Bronze Age (ca. 2000 - 1600 BC) just 16 sites have yielded Syrian bottles, and the spatial distribution of this type of vessel was confined mainly in northern Syria and south-eastern Anatolia (Fig. 9). Kaneš is the westernmost and only central Anatolian site in which Syrian bottles have been found (see Emre 1999), with this site yielding one bottle from a cist grave belonging to the lower town's level $\mathrm{Ib}$ (ca. 1835-1700 BC) and five bottles from level Ia graves (ca. 17th BC). Only four northern Mesopotamian sites out of fifteen have yielded vessels dated to the Middle Bronze Age I (ca. 20001800 BC): Tilbeshar Höyük (1 bottle from area D, level IV A; Kepinski 2005, 150); Ebla (8 bottles from Favissae F. 5238 and F. 5327; Marchetti and Nigro 1997, 10-11), Tell ShiyukhTahtani (2 bottles from tombs T. 119 and T. 120, phase 8; Falsone and Sconzo 2010, 6-7), and Lidar Höyük (3 bottles from phase $3 / 2$ and phase 2; Kaschau 1999, 259, 262, 265). The striking difference in the distributions of this type of ceramic shape between those two periods raises legitimate questions. Why did the evidence of Syrian bottles decrease in the Middle Bronze Age in comparison with the third millennium $\mathrm{BC}$ ? Is this phenomenon related to a changed political and economic situation in northern Mesopotamia and Anatolia? What is noteworthy is that the evidence for Syrian bottles has strongly decreased in central Anatolia between the third and the second millennium BC. In particular, if in the Early Bronze Age Kaneš yielded several bottles from the main mound's levels 12-17 (Özgüç 1986a, 34-37), in the early second millennium the same site has yielded six examples, with only one from the archaeological level (lower town's level Ib, ca. 1835-1700 BC) contemporary to the Old Assyrian commercial colony period. This aspect could suggest that the Assyrians may have excluded from the trade system occurring in northern Mesopotamia and central Anatolia foreign merchants and their own goods. In fact, Syrian bottles and their contents were originally manufactured in northern Syria and probably not traded by the Assyrians merchants. Hence, it seems legitimate to speculate that the trade in this kind of fine ware was related to a circuit associated with the city-states of Mari, Emar and Aleppo that may have held commercial control in the area to the west of the Euphrates. A simpler explanation could be that Syrian bottles or their contents were no longer a highly demanded good in central Anatolia in the second millennium because either fine oil started being carried in a different kind of container or a change of fashion had occurred, perhaps as witnessed by the lack of evidence for local imitations in this region either (Bachuber 2012, 58).

\section{Lapis lazuli}

\subsection{Sources of lapis lazuli}

Even today, the potential places of origin of the lapis lazuli found in the ancient Near East are little understood, largely because the area with the highest likelihood of yielding lapis lazuli mines (Afghanistan and Tajikistan) is fraught with great political instability and is currently inaccessible to archaeological research. Furthermore, notwithstanding the recent development of various techniques for provenance analysis (e.g. Law 2014; Re et al. 2011; Zöldföldi et al. 2006), such studies have still not been widely applied to archaeological samples, thus severely hindering any attempt to correlate 
sources and finished products. With the current knowledge, out of 13 deposits known worldwide (Zöldföldi et al. 2006), the Badakhshan mines in Afghanistan (particularly Sar-i Sang) are the only ones that have been with some confidence identified as a source of lapis lazuli for the EBA-MBA Near East (Herrmann 1968, 22-29; Law 2014, 420-421). Other potential, albeit presently unconfirmed, sources are the Pamir deposits in Tajikistan, ca $130 \mathrm{~km}$ away from Sar-i Sang (Fig. 10; Law 2014, 426). On the other hand, the Lake Baikal source (in north-eastern Russia) was likely too far away to have played any significant role in the exchange of lapis lazuli in south-western Asia (Law 2008, 804-816; Wilkinson 2014, 125).

Despite the fuzziness of the picture, both archaeological and written evidence confirm that lapis lazuli reached Mesopotamia from regions further to the east. Archaeologically, both the earliest and richest attestations of lapis lazuli manufacture come from the area closest to the Afghan/Tajik sources (see below). Moreover, texts from Ur, Lagash (ca. 2100-2000 BC) and Mari (ca 1800-1750 BC) identify places like Aratta (possibly south-eastern Iran), Elam (southern Iran), Dilmun (possibly Bahrain) and Meluhha (possibly the Indus valley) as the regions through which lapis lazuli was acquired by Mesopotamian merchants (Joannès 1996; Michel 2001; Moorey 1994, 85-87; Pettinato 1974, 77-78; Villard 1986, 406).

\subsection{Lapis lazuli manufacture}

Most of the EBA/MBA lapis lazuli artefacts were shaped as beads (74\%), inlays (17\%), pieces of composite objects $(8 \%)$ and seals $(0.7 \%)$ (Casanova 2000, 174; Casanova 2001, 155). The extreme rarity of larger artefacts $(0.3 \%)$ is probably related with the thin tabular nature of the lapis lazuli deposits (Herrmann 1968, 24), and the corresponding difficulty in carving substantial threedimensional objects. Direct archaeological evidence for lapis lazuli production, in the form of drill bits, working debris and unfinished artefacts, is abundant in Afghanistan, Pakistan, and Iran. Sites with identifiable lapis lazuli workshops include Mehrgarh, Tepe Hissar, Mundigak, Shortugai, Sarazm, Shahr-i Sokhta, Shahdad, Tepe Farukhabad and Tepe Malyan, all dated between ca 4000/3700 and 2000 BC (Fig. 10, Casanova 2000, 177; Moorey 1994, 89; Tosi and Vidale 1990). Within the study area, while contextual archaeological evidence for EBA or MBA lapis lazuli workshops is currently missing, local manufacture is confirmed by the occurrence of products in local styles. Furthermore, unworked lapis lazuli nodules are found at a number of sites across the Near East, including Late Uruk Jebel Aruda and Susa, ED III Ur, EB IVa Ebla and MBA Kaneš (Fig. 10; Aubet 2013, 299; Woolley 1934, 372). Several textual references also indicate the procurement of raw nodules from Mari, Larsa and Lagash between the late third and early second millennia BC likely in order to be locally manufactured (Biga 2014, 98; Pettinato 1974, 78; Villard 1986, 406).

\subsection{Exchange of lapis lazuli}

The earliest attestation of lapis lazuli working comes from Neolithic Mehrgarh in Pakistan, while beads from Yarim Tepe (late sixth millennium BC) represent the earliest import in northern Mesopotamia (Tosi and Vidale 1990). However, it is only in the Uruk and Jemdet Nasr periods (late fourth millennium BC) that lapis lazuli customarily reached Mesopotamia, both in raw and finished form (Fig. 11; Herrmann 1968, 29-36; Moorey 1994, 88-89; Tosi 1974). It also became common in Egypt during the Naqada period and Dynasties 0-1 (Crawfoot Payne 1968; Hendrikx and Bavay 2002, 66), but surprisingly not in contemporary southern Levant where only one bead was found in Ghassulian levels at Nahal Mishmar (Bar-Yosef Mayer et al. 2014, 268). After its apparent disruption of lapis lazuli exchanges in the early third millennium (ED I, Egyptian second-third Dynasties), 
witnessed in both Egypt and Mesopotamia (Crowfoot and Payne 1968, 58-59; Herrmann 1968, 37), lapis lazuli returned to be popular for the remainder of the EBA (Fig. 12). For this period, southern Mesopotamia in particular yields rich assemblages epitomised by the cemetery of Ur, and in particular its "Royal" section dated to the ED IIIb (Woolley 1934). According to Casanova, this site alone has produced $75 \%$ of the ca 30,000 lapis lazuli items recorded across Syria, Mesopotamia and central Asia between the Neolithic and LBA (2000, 172-173; 2001, 152-154).

In parallel with the trend in Mesopotamia, considerable amounts of lapis lazuli are found in Egypt in contexts belonging to the fourth-sixth Dynasties (Crawfoot Payne 1968, 59; Sowada 2009, 184). As with previous periods, the southern Levant was seemingly cut out of the lapis lazuli exchange network, with only a few pieces from Byblos and Bab edh-Dhra (Sowada 2009, 94-95). Despite the flimsy archaeological evidence, it is possible that Byblos may have funnelled lapis lazuli further south to Egypt via a maritime route, something that would explain the dearth of this material in the area south of this site (Aubet 2013, 237).

It is not until the late EBA (ca 2400-1950 BC) that a handful of lapis lazuli objects finally reached central and western Anatolia at sites like Troy, Bozüyük, Kaneš, Yassıhöyük, and Acemhöyük (Fig. 12). They are mostly small items like beads, inlays and cylinder seals, whose typology and motifs clearly point to a Mesopotamian origin of the pieces (cf. Özgüç 1986a, 45). Considering this, the battle axe from Troy "treasure L" (ca. 2400-2200 BC) represents an astonishing and unique find: at $1.3 \mathrm{~kg}$ and $28 \times 7 \mathrm{~cm}$ in size, it is one of the largest lapis lazuli artefacts ever recovered in the Bronze Age Near East. ${ }^{6}$ However its shape, closely matched by three other nephrite and jadeite battle axes found in the same hoard, points to a manufacturing place somewhere between Troy itself and the eastern Black Sea coast (Antonova et al. 1996, 219-222, cat.no.169), an area that so far yielded a very limited number of lapis lazuli objects (Apakidze 1999). Whether manufactured locally or elsewhere in the Pontic region, the battle axe is a witness to the extreme importance of Troy as an interregional commercial centre, able to attract and funnel a large range of luxury products circulating within different trade circuits (cf. also Korfmann 2001). Interestingly, the remainder of the Aegean basin seems to have been largely outside the lapis lazuli trade network, with the retrieval of a single bead from Koumasa on Crete dated to the latest third millennium (Colburn 2008, Table 4).

During the MBA, lapis lazuli trade seems to have witnessed a significant contraction and became extremely rare in southern Mesopotamia, a phenomenon possibly at least in part connected with the collapse of maritime contacts with the Indus valley (Fig. 13, Moorey 1994, 89-90). In this phase, circulation of lapis lazuli seems restricted mainly to northern Levant and northern Mesopotamia, with small quantities reaching central Anatolia. For the latter, while archaeological evidence is scarce, OAT-period documents (ca. 1970-1700 BC) frequently mention the import of lapis lazuli into central Anatolia by Assyrian merchants, in quantities that often reach several kilos (Michel 2001; Veenhof and Eidem 2008, 84, 147, 184, 188, 213, notes 219, 231, 351, 678, 810, 920). ${ }^{7}$ On the other hand, western Anatolia and the Aegean basin remained largely outside the lapis lazuli exchange network, with only a handful of small artefacts retrieved at Petras, Archanes, Aghia Triada and Palaikastro on Crete (Betancourt et al. 2017; Colburn 2008, 208; Platon et al. 1977, no.286).

\footnotetext{
${ }^{6}$ As a comparison, it is worth noting that the lapis lazuli raw nodules found in the destruction of Ebla's Palace G weighed between 100 and 1000gr (Peyronel 2012, 477).

${ }^{7}$ In most cases, lapis lazuli was exchanged in small quantities of few hundred grams each, either as lumps or finished artefacts; however, two raw nodules of 3 and $6 \mathrm{~kg}$ respectively are mentioned in separate occasions (Michel 2001, 347; Veenhof and Eidem 2008, 84, note 351).
} 


\section{Discussion}

\subsection{Timing the development of long-distance exchange networks}

In the third and early second millennia $\mathrm{BC}$, the general picture is one of regional specialisation in the production of goods, framed within a system of long-distance contacts bridging different geographic and cultural areas such as Mesopotamia and Anatolia. The system consisted of a series of interconnected and overlapping trading circuits interacting among themselves and built around a few centres specialising in commercial brokerage (for the MBA, see Larsen 1987, 53-54; Barjamovic, in press). From this perspective, the case studies presented above clearly show that ivories, lapis lazuli artefacts, perfume bottles and pan-balance weights found in Anatolia are useful markers of contacts with societies living in the Fertile Crescent. They can be employed, together with other evidence not analyzed here in detail, to reconstruct the extent, structure and mechanisms of some large-scale exchange circuits active between Anatolia, the Levant, and northern Mesopotamia during the third and early second millennia BC.

The appearance of metrological tools (pan balance weights) in Anatolia, as well as the metrological knowledge associated with their use (units of measure and the ability to calculate fractions and multiples across different systems), is a strong evidence for direct contacts between Anatolian and Mesopotamian/Levantine communities. With the available data, the earliest pan balance weights occur in western Anatolia around 2900-2750 BC, a horizon that precedes by several centuries the accepted date for the flourishing of the international exchange networks in Anatolia at around 2500 BC (cf. the "Anatolian Trade Network" and "Great Caravan Route" models, Efe 2007; Şahoğlu 2007). However, given the almost complete absence of extensively excavated and well-published Late Chalcolithic and early EBA contexts in central Anatolia, it is possible that earlier direct contacts may have existed, particularly with areas closer to the Fertile Crescent.

The chronological and spatial analysis of different categories of Levantine/Mesopotamian-originated or inspired products (some of which treated here) further suggests that the long-distance exchange networks reaching Anatolia gradually expanded throughout the EBA, particularly in the range of products and technological know-how that circulated across them. For instance, contemporary with the introduction of metrological systems (ca 2900-2750 BC) is also the adoption and local adaptation of simple sealing practices on vessels and other containers (Massa 2016, 130-145; Rahmstorf 2006b, 62-67). The arrival of the first bone pigment tubes in the Aegean can be dated around 2700-2600 BC (Genz 2003, 41-43), approximately contemporary with the earliest ivories on Crete. The earliest lapis lazuli objects and perfume bottles are instead attested around 2400-2300 BC, contemporary with the adoption of the potter's wheel technology (cf. Türkteki 2010 and 2013).

Furthermore, the spatial distribution of different weight shapes and units of measure reveals the presence of at least two distinct, albeit overlapping, exchange networks reaching Anatolia during the third and early second millennia BC. The first is a prominently sea-borne network stretching between the Levantine coast and the Aegean basin via a maritime route that touched the southern Anatolian coast (Fig. 14). Its identification remains problematic, as there is virtually no excavated EBA/MBA coastal site between Yumuktepe in Cilicia and Iasos in the south-eastern Aegean, as well as very little investigation on the northern coast of Cyprus. This notwithstanding, during the EBA this network is witnessed by the ivories mentioned above, the bone pigment containers (Genz 2003), the sealimpressed pottery (Massa 2016, 138; Rahmstorf 2006b, 62-67), as well as a range of small Levant and Egypt-originated luxury items in mid-late EBA Crete (Broodbank 2000: 283-284; Colburn 2008). While Cyprus seems to have been left out of this circuit in the earlier part of the EBA, there is evidence for its inclusion at least from the Philia phase (ca 2500-2400 BC) onward, in the form of 
small amounts of pottery (from Crete, Anatolia and the Levant), faience beads and gypsum/calcite vessels (from Egypt and the Levant, Knapp 2013: 307-309). Along this route, metals also seem to have been exchanged, as witnessed by provenance analysis on EBA metals from the Aegean, Cyprus and the Levant that show small amounts of outliers coming from either end of the network (Kayafa et al. 2000: 43-44; Massa 2016: 190-195; Philip et al. 2003; Stos and Gale 2010; Webb et al. 2006). In addition to raw materials and finished products, also ideas and technologies certainly travelled along the southern Anatolian coast: a prime example is provided by the westward spread of metrology and sealing practices in the early EBA (cf. also Broodbank 2014: 335-336, fig. 7.50; Rahmstorf 2006b; 2011; 2016). It is striking that all these features appear almost exclusively at sites near the coast (Fig. 14). Somewhat surprisingly, evidence for this route during the early MBA (contemporary with the OAT) is however rather scanty, as also highlighted by the almost complete absence of Aegean ivories in this phase (cf. also Krzyszkowska 2005, 70-74). During the later MBA, this route seems to have had Crete as its end point, while the Aegean basin appears to lie outside of the maritime network (Alberti 2012; Colburn 2008, 203; Watrous 1998).

The second exchange network is composed of a bundle of interweaving routes that crossed the eastern Taurus and Anti-Taurus Mountains at different passes, connecting northern Syria with central Anatolia and beyond. During the EBA, it is marked by the distribution of sphendonoid weights and the 8.3 gr unit only at inland sites (cf. also Rahmstorf 2006b; 2011), as well as of lead anthropomorphic figurines (Massa 2016, 233-235), Harappan carnelian beads (Ludvik et al. 2015, 29; Peyronel 2015, 75-79), Syrian bottles (and their imitations) and lapis lazuli artefacts (Fig. 14). In the MBA, the available evidence suggests that the exchange circuit shrank and only reached as far as the central Anatolian plateau, while areas to the west (western Anatolia and eastern Thrace) remained apparently outside the network.

\subsection{The infrastructure of trade}

During the OAT there is extensive written evidence for the existence not only of professional traders, but also of maintained roads, bridges, ferries, inns, relay stations and guards along major routes (Barjamovic 2011, 3-37; Dercksen 1996, 64-67; Larsen 2015, 157, 176-178). The trends highlighted in the analysis above strongly imply that a similar setting may have also existed in Anatolia already during the mid-late third millennium BC. In particular, the spatial distribution of Mesopotamian/Levantine-originated artefacts indicates directional trade (as opposed to down-the-line exchanges): while these features are unsurprisingly found more densely in areas closer to the source, in Anatolia they are almost exclusively found in major EBA centres such as Alişar Höyük, Kaneš, Yassıhöyük, Acemhöyük, and Poliochni. Furthermore, they have been retrieved in large numbers at EBA Troy, at the north-western end of the maritime and overland interregional networks. Such a distribution is possible only if intermediaries (i.e. professional traders) were involved in the exchanges (cf. Renfrew 1975, 41-51). Another indirect evidence for the existence of merchants is the presence of domesticated donkeys (a species not native to central Anatolia) in late EBA contexts at Kaman Kalehöyük, Acemhöyük (Arbuckle 2013, 56-59; Atıc1 2003, 2005) and perhaps Kaneš. ${ }^{8}$ Donkeys were probably domesticated in north-eastern Africa as early as the fifth millennium BC, appeared slightly later in the Levant, and were employed in Mesopotamia since Late Uruk times (Grigson 1993,

\footnotetext{
${ }^{8}$ At Kaneš, in the absence of zooarchaeological studies targeting the EBA assemblages, evidence for donkey comes from the portrait of an equid being loaded by a person, depicted on an "alabaster idol" typical of Kültepe levels 12-11, ca 2200-1950 BC (Bilgi 2012, fig.834). For the ensuing MBA, the presence of donkeys is directly attested by faunal remains (Atic1 2014: table 2).
} 
645-646; Littauer and Crouwel 1979:23-24; Rossel et al. 2008; Wilkinson 2014:47-51). Their presence in late EBA Anatolian contexts suggests that its introduction may have been connected with the presence of professional traders coming from regions further to the south-east.

It further needs to be stressed that, with the available evidence, Mesopotamian and Levantineoriginated products and technologies reaching Anatolia were mostly related to elite practices either in the context of administration or display and consumption of exotica. It can be argued that the objects themselves were in most cases the result of specialized manufacture and, at least for ivory and lapis lazuli, there is clear archaeological evidence that production and exchange was in some cases tightly connected with palace economies already in the mid-late EBA (e.g. at Ebla, Peyronel 2012; 2016). By the early Middle Bronze Age, cities such as Aššur, Kaneš, Aleppo, Ebla, Mari, Ugarit and Sippar owed most of their prosperity to the trade of metals (e.g. tin, copper and silver), textiles, oils and aromatics (c.f. Bonechi 1992, 11-13; Dalley 2002; Dercksen 2005; Veenhof and Eidem 2008, 82-95; Aubet 2013, 141). It is important to stress that all known forms of goods that were circulated in these long-distance exchange networks were characterised by a high value and relatively low bulk, an effect of the costs involved in transport.

\subsection{The importance of the Anatolian metal}

These observations raise the question of what were the Anatolian products traded in exchange for Mesopotamian/Levantine luxury artefacts. For the OAT, written sources clearly state that Assyrian interest focused on Anatolian metals, and describe donkey caravans customarily returning to Aššur loaded with silver bullion (Barjamovic 2011, 15; Dercksen 1996, 151-154; Larsen 2015, 63; Veenhof 1997, 339-340; Veenhof and Eidem 2008, 195). Quite surprisingly, Anatolia is rarely mentioned in academic research as a possible major source of metal (particularly silver and gold) for the EBA Near East. There is, however, little doubt that its vast metal deposits are the most likely trigger for the creation of stable interregional exchange networks reaching Anatolia (Fig. 15). In fact, across the whole peninsula (and particularly in Çorum, Yozgat and Niğde regions, central Anatolia) extractive metallurgy takes off during the mid-fourth millennium BC, and by the early third millennium $\mathrm{BC}$ evidence for mines, smelting sites and intra-settlement metallurgical workshops becomes commonplace (cf. Schoop 2011; Wagner and Öztunalı 2000; Yalçın and Maass 2013; Yalçın et al. 2015; Yener 2000; Yener et al. 2015).

A direct connection between metallurgy and interregional networks is provided by the contextual analysis of the Anatolian stone weights, which are often found in areas dedicated to metallurgical activities (Massa 2016, 126-127; cf. also Rahmstorf 2006b, 75-76 for similar observations in the western Aegean EBA). Furthermore, EBA and MBA Anatolian weights very rarely exceed $100 \mathrm{~g}$ (Kool 2012, table 1; Massa 2016, 125, table 5.6), and can thus reasonably thought to have been employed for weighing high-value/low-bulk items like silver and gold (cf. also Rahmstorf 2010, 689 for the Aegean EBA). Moreover, despite the general scarcity of provenance analysis on Mesopotamian metals, a few lead isotope studies suggest that the earliest central Anatolian metals (from Bolkardağ in the Taurus Mountains and Çorum) might have reached the Fertile Crescent during the late fourth-early third millennia BC. They include a few Late Uruk/Jemdet Nasr objects in northern Mesopotamia (Begemann and Schmitt-Strecker 2009, 21-23), some copper-based and silverbased items from Tell Judeideh in the Amuq valley (phases F and G, Yener et al. 1991, 555), and one EB I/II chisel from the southern Levantine site of Pella (Philip et al. 2003, 87, table 4). Additionally, the appearance and subsequent spread of metal ingots in the late fourth-early third millennia BC is a good indicator that metallurgical production was, at least in part, meant to enter the long-distance 
exchange networks. This is suggested by the very shape of these objects (often flat and standardized in shape, easy to stack), which seem tailored to maximize space and facilitate transport (Bevan 2010, 505-510; Massa 2016, 189-190).

Lastly, textual evidence indicates that silver replaced copper as the standard for most transactions in northern Levant and Mesopotamia starting in late ED III times (ca 2500-2350 BC, Helwing 2014, 417-418; Peyronel 2014, 355-356). Ebla's archives in particular reveal how silver was employed both as currency in a complex redistributive system linked to the Palace, and as raw material in most of the gifts exchanged among the Eblaite elite and with other dignitaries (Archi and Biga 2003; Archi 2013; Peyronel 2014, 362-365). Jennifer Ross estimates that the Eblaite archives recorded ca 30 tonnes of silver and 3 tonnes of gold transiting through the Palace, across some 40 years (1999, 244-245). If we assess this figure within the context of the palatial economies in northern Levant and Mesopotamia, we can get a glimpse of the staggering amounts of precious metals circulating in the area at any given time during the late EBA. While other sources certainly existed (prominently in north-western Iran, Helwing 2014, 415-417; Nezafati and Pernicka 2012), the Anti-Taurus (Ergani Maden) and central Taurus (Bolkardağ, Niğde) silver and gold deposits were closest to northern Syria (Fig. 15) and were likely a major source for Ebla, only $200 \mathrm{~km}$ away as the crow flies. Further afield, western Anatolia was probably another important source of precious metals, particularly if we accept Gojko Barjamovic's localization of Purušhaddum (a major OAT silver trade centre at the westernmost end of the Assyrian trade) at the interface between the central Anatolian plateau and western Anatolian highlands $(2011,357-378)$. In addition, the participation of Troy in the interregional exchange networks (particularly during the mid-late third millennium BC) may be interpreted along similar lines, given its proximity to important gold deposits in the Troad and Thrace. All this evidence strongly suggests that Anatolian metallurgy may have been the single most important factor in igniting the development of stable long-distance relations across the Taurus Mountains, possibly as early as $3500-3200 \mathrm{BC}$.

\subsection{Continuity and change between the late EBA and MBA trade networks}

As a last point, it is worth assessing the elements of continuity and change between the late third and the early second millennia BC long-distance exchange networks. Among the factors of continuity one can certainly include the involvement of the same major centres in both periods, including Knossos, Acemhöyük, Kültepe, Alişar Höyük, Alacahöyük, Tarsus, Byblos, Ebla, Tell Brak, Mari, Aššur, Kiš, Ur, and Uruk among others. Because many of these sites continued to play an important role within these networks, it is also probable that the routes connecting them may have been relatively stable as well, though at present there is no direct evidence to confirm this. As argued above, it is likely that the main interest of EBA Levantine and Mesopotamian merchants in Anatolia may have been access to silver and gold, as it is clear during the MBA. In addition, the main metrological units (and especially the 7.8g, 8.3-8.5g and $9.4 \mathrm{~g}$ units) common in the third millennium continued to be used in the following period, and similarly the sphendonoid weights remained the most common type across Anatolia, Mesopotamia and the Levant. Further to this, even though individual artefact types may have changed through time, the categories of goods that were circulating in both periods are also rather similar and include ivories, lapis lazuli, perfumes/oils and metal products.

This notwithstanding, there are also some important factors of change witnessed in Anatolia at the transition between the EBA and MBA periods, the most important being changes in the socioeconomic and political context within which interregional trade occurred. Writing (in the form of cuneiform tablets) made its first appearance in central Anatolia roughly contemporary with the first 
archaeological evidence of Assyrian commercial and residential quarters (Hawkins 1986; van den Hout 2010, 99-101; Waal 2012, 287-288), and it is thus very likely associated with the more stable presence of Mesopotamian merchants in the area. Available data also suggest that, in central Anatolia, the first use of door sealings (Weingarten 1990) and the first widespread use of cylinder seals as administrative tools (Massa 2016, 136; Massa and Tuna, in press) cannot be dated before the earliest second millennium BC. These innovations reflect important steps toward a more bureaucratic and centralized administrative system of the Anatolian societies, a situation that likely affected trade mechanisms. In addition to this, there is at present good evidence that, during the early second millennium BC, both the maritime and overland legs of the interregional networks contracted in size. For instance, during the late EBA, Levant-originated products reached, albeit in very modest quantities, as far as mainland Greece and the northern Aegean, while during the MBA they seem mostly restricted to Crete. Similarly, during the late third millennium the overland network stretched up until the Troad and eastern Thrace, while in the OAT phase it seems limited to the central Anatolian plateau (Cappadocia and Kizılırmak bend in particular). It is difficult at present to identify a plausible reason for this contraction; tentatively, it might be connected with the reduction of social complexity in all the areas excluded by the MBA long-distance exchange networks, namely western Anatolia, the Cyclades and mainland Greece. With the notable exception of Crete, in the latest thirdearly second millennia BC the communities in and around the Aegean basin seem to have witnessed the disappearance of most regional centres, a drop in overall settlement numbers, and the disappearance of seals as administrative tools (Massa and Şahoğlu 2015, 72-74; Wiener 2013; Wiener 2014, 5-8).

\section{Conclusions}

Our work aimed at shedding light on the relation between the Early and Middle Bronze Age exchange networks connecting Anatolia with the Fertile Crescent, and at assessing the degree of similarity between the two periods. The paper has hopefully been successful in highlighting significant elements of continuity that strongly suggest that the Old Assyrian Trade network is only the mature stage of a process started at least during the late fourth millennium BC. A more in-depth understanding of the origins, mechanisms and developments of this process will be paramount to better assess the role of Anatolia within the broader Near Eastern world, not only as a source of raw materials, but as a centre of technological and cultural innovation.

The analysis presented here has also brought together a range of archaeological evidence for the existence of at least two distinct long-distance exchange networks reaching Anatolia, one essentially sea-borne and connecting the Levant with the Aegean world, the other land-locked and connecting inland Anatolia with northern Levant and Mesopotamia. While these patterns have been highlighted in previous research, this work is the first to analytically investigate their shape and extent, and their development through time.

More importantly, the paper has hopefully underlined the potential of a multi-proxy, spatially-oriented analysis for the study of exchange mechanisms. In particular, while the results of this research are to be considered preliminary, they have highlighted the need for more archaeology-driven investigation of the Old Assyrian Trade network, whose analysis has so far heavily relied on textual evidence.

\section{Acknowledgments}


We would like to thank three anonymous reviewers for their helpful insights that considerably improved this paper. Any mistakes and inaccuracies remain, of course, our own. This research did not receive any specific grant from funding agencies in the public, commercial, or not-for-profit sectors.

\section{Supplementary data and code}

The datasets used in this work can be found in the journal data paper by Massa and Palmisano (in press) and UCL Discovery online repository: http://dx.doi.org/10.14324/000.ds.10027581

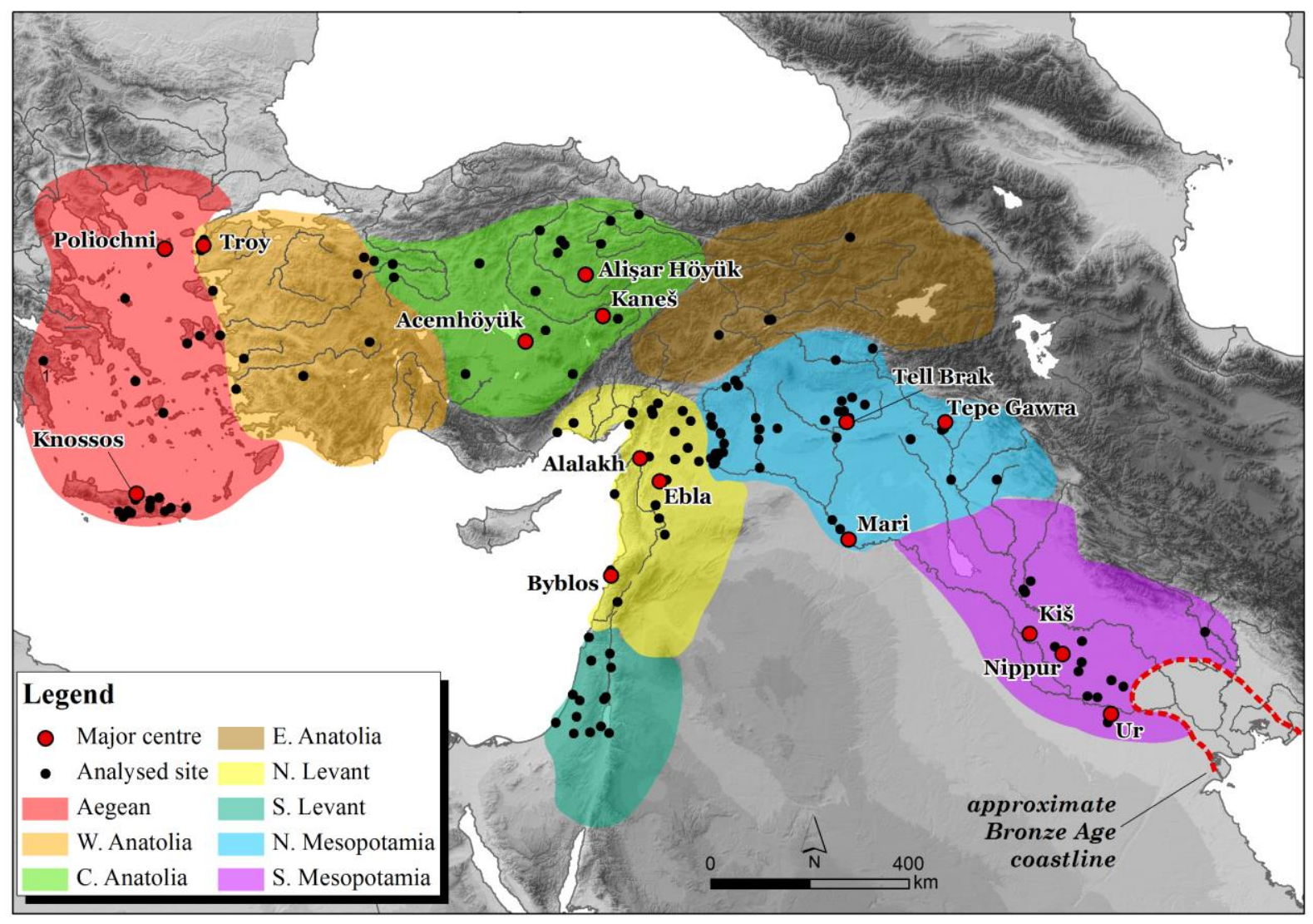

Figure 1. Map of the study area and analysed sites, showing the major geo-cultural regions mentioned in the text. 


\begin{tabular}{|c|c|c|c|c|c|c|}
\hline \multirow{2}{*}{\multicolumn{2}{|c|}{ Shapes }} & \multirow{2}{*}{\multicolumn{5}{|c|}{ Zones }} \\
\hline & & & & & & \\
\hline bell-shaped & $\begin{array}{c}\text { Count } \\
\text { (expected count) }\end{array}$ & $\begin{array}{c}\text { Anatolia } \\
0 \\
(2.5)\end{array}$ & $\begin{array}{c}\text { Levant } \\
0 \\
(2.2)\end{array}$ & $\begin{array}{c}\text { Mesopotamia } \\
7 \\
(2.3) \\
\end{array}$ & $\begin{array}{c}\text { Total } \\
7\end{array}$ & $\begin{array}{c}\% \\
1.92\end{array}$ \\
\hline cone & $\begin{array}{c}\text { Count } \\
\text { (expected count) }\end{array}$ & $\begin{array}{c}0 \\
(1.4)\end{array}$ & $\begin{array}{c}0 \\
(1.3)\end{array}$ & $\begin{array}{c}4 \\
(1.3)\end{array}$ & 4 & 1.10 \\
\hline cubic & $\begin{array}{c}\text { Count } \\
\text { (expected count) }\end{array}$ & $\begin{array}{c}0 \\
(1.1)\end{array}$ & $\begin{array}{c}1 \\
(0.9)\end{array}$ & $\begin{array}{c}2 \\
(1)\end{array}$ & 3 & 0.82 \\
\hline duck & $\begin{array}{c}\text { Count } \\
\text { (expected count) }\end{array}$ & $\begin{array}{c}1 \\
(6.8)\end{array}$ & $\begin{array}{c}3 \\
(6)\end{array}$ & $\begin{array}{c}15 \\
(6.2)\end{array}$ & 19 & 5.22 \\
\hline cylinder & $\begin{array}{c}\text { Count } \\
\text { (expected count) }\end{array}$ & $\begin{array}{c}3 \\
(7.2)\end{array}$ & $\begin{array}{c}10 \\
(6.3)\end{array}$ & $\begin{array}{c}7 \\
(6.5) \\
\end{array}$ & 20 & 5.49 \\
\hline dome & $\begin{array}{c}\text { Count } \\
\text { (expected count) }\end{array}$ & $\begin{array}{c}0 \\
(3.6)\end{array}$ & $\begin{array}{c}7 \\
(3.2)\end{array}$ & $\begin{array}{c}3 \\
(3.2)\end{array}$ & 10 & 2.75 \\
\hline hemispheric & $\begin{array}{c}\text { Count } \\
\text { (expected count) }\end{array}$ & $\begin{array}{c}0 \\
(2.1)\end{array}$ & $\begin{array}{c}6 \\
(1.9)\end{array}$ & $\begin{array}{c}0 \\
(2)\end{array}$ & 6 & 1.65 \\
\hline lentoid & $\begin{array}{c}\text { Count } \\
\text { (expected count) }\end{array}$ & $\begin{array}{c}0 \\
(1.1)\end{array}$ & $\begin{array}{c}0 \\
(0.9)\end{array}$ & $\begin{array}{c}3 \\
(1)\end{array}$ & 3 & 0.82 \\
\hline loaf & $\begin{array}{c}\text { Count } \\
\text { (expected count) }\end{array}$ & $\begin{array}{c}0 \\
(0.4)\end{array}$ & $\begin{array}{c}0 \\
(0.3)\end{array}$ & $\begin{array}{c}1 \\
(0.3)\end{array}$ & 1 & 0.27 \\
\hline ovoid & $\begin{array}{c}\text { Count } \\
\text { (expected count) }\end{array}$ & $\begin{array}{c}12 \\
(10.4)\end{array}$ & $\begin{array}{c}5 \\
(9.2)\end{array}$ & $\begin{array}{c}12 \\
(9.5)\end{array}$ & 29 & 7.97 \\
\hline pear-shaped & $\begin{array}{c}\text { Count } \\
\text { (expected count) }\end{array}$ & $\begin{array}{c}0 \\
(1.8)\end{array}$ & $\begin{array}{c}5 \\
(1.6) \\
\end{array}$ & $\begin{array}{c}0 \\
(1.6) \\
\end{array}$ & 5 & 1.37 \\
\hline rectangular & $\begin{array}{c}\text { Count } \\
\text { (expected count) }\end{array}$ & $\begin{array}{c}2 \\
(0.7)\end{array}$ & $\begin{array}{c}0 \\
(0.6)\end{array}$ & $\begin{array}{c}0 \\
(0.7)\end{array}$ & 2 & 0.55 \\
\hline sphendonoid & $\begin{array}{c}\text { Count } \\
\text { (expected count) }\end{array}$ & $\begin{array}{c}86 \\
(66.8)\end{array}$ & $\begin{array}{c}42 \\
(59.1)\end{array}$ & $\begin{array}{c}59 \\
(61.1)\end{array}$ & 187 & 51.37 \\
\hline spheroid & $\begin{array}{c}\text { Count } \\
\text { (expected count) }\end{array}$ & $\begin{array}{c}8 \\
(13.9)\end{array}$ & $\begin{array}{c}28 \\
(12.3)\end{array}$ & $\begin{array}{c}3 \\
(12.8)\end{array}$ & 39 & 10.71 \\
\hline spool & $\begin{array}{c}\text { Count } \\
\text { (expected count) }\end{array}$ & $\begin{array}{c}18 \\
(7.9)\end{array}$ & $\begin{array}{c}4 \\
(7)\end{array}$ & $\begin{array}{c}0 \\
(7.1)\end{array}$ & 22 & 6.04 \\
\hline square & $\begin{array}{c}\text { Count } \\
\text { (expected count) }\end{array}$ & $\begin{array}{c}0 \\
(2.5)\end{array}$ & $\begin{array}{c}4 \\
(2.2)\end{array}$ & $\begin{array}{c}3 \\
(2.3)\end{array}$ & 7 & 1.92 \\
\hline Total & & 130 & 115 & 119 & & \\
\hline
\end{tabular}

Table 1. Shapes of Early Bronze Age balance weights tabulated against their distribution zones. The two sets of values show the observed number of weights divided per shape in each region ("count") compared with their expected count in case they were randomly distributed. A chi-squared test (pvalue <0.001) reveals that the shapes of balance weights are significantly associated with their distribution zones. 


\begin{tabular}{|c|c|c|c|c|c|c|}
\hline \multicolumn{2}{|c|}{ Shapes } & \multicolumn{5}{|c|}{ Zones } \\
\hline animal head & $\begin{array}{c}\text { Count } \\
\text { (expected count) }\end{array}$ & $\begin{array}{c}\text { Anatolia } \\
1 \\
(0.2)\end{array}$ & $\begin{array}{c}\text { Levant } \\
0 \\
(0.4)\end{array}$ & $\begin{array}{c}\text { Mesopotamia } \\
0 \\
(0.4) \\
\end{array}$ & $\begin{array}{c}\text { Total } \\
1\end{array}$ & $\begin{array}{c}\% \\
0.17\end{array}$ \\
\hline biconical & $\begin{array}{c}\text { Count } \\
\text { (expected count) }\end{array}$ & $\begin{array}{c}2 \\
(0.4)\end{array}$ & $\begin{array}{c}0 \\
(0.9)\end{array}$ & $\begin{array}{c}0 \\
(0.8)\end{array}$ & 2 & 0.34 \\
\hline boar-head & $\begin{array}{c}\text { Count } \\
\text { (expected count) }\end{array}$ & $\begin{array}{c}0 \\
(0.4)\end{array}$ & $\begin{array}{c}0 \\
(0.9)\end{array}$ & $\begin{array}{c}2 \\
(0.7)\end{array}$ & 2 & 0.34 \\
\hline bovine-head & $\begin{array}{c}\text { Count } \\
\text { (expected count) }\end{array}$ & $\begin{array}{c}1 \\
(0.2)\end{array}$ & $\begin{array}{c}0 \\
(0.4)\end{array}$ & $\begin{array}{c}0 \\
(0.4)\end{array}$ & 1 & 0.17 \\
\hline cone & $\begin{array}{c}\text { Count } \\
\text { (expected count) }\end{array}$ & $\begin{array}{c}0 \\
(0.2)\end{array}$ & $\begin{array}{c}1 \\
(0.4)\end{array}$ & $\begin{array}{c}0 \\
(0.4)\end{array}$ & 1 & 0.17 \\
\hline cubic & $\begin{array}{c}\text { Count } \\
\text { (expected count) }\end{array}$ & $\begin{array}{c}0 \\
(0.4)\end{array}$ & $\begin{array}{c}2 \\
(0.8)\end{array}$ & $\begin{array}{c}0 \\
(0.8)\end{array}$ & 2 & 0.34 \\
\hline duck & $\begin{array}{c}\text { Count } \\
\text { (expected count) }\end{array}$ & $\begin{array}{c}3 \\
(12.4) \\
\end{array}$ & $\begin{array}{c}1 \\
(27.3) \\
\end{array}$ & $\begin{array}{c}60 \\
(24.3) \\
\end{array}$ & 64 & 11.02 \\
\hline cylinder & $\begin{array}{c}\text { Count } \\
\text { (expected count) }\end{array}$ & $\begin{array}{c}0 \\
(4.9)\end{array}$ & $\begin{array}{c}24 \\
(10.7)\end{array}$ & $\begin{array}{c}1 \\
(9.4)\end{array}$ & 25 & 4.30 \\
\hline disc-shaped & $\begin{array}{c}\text { Count } \\
\text { (expected count) }\end{array}$ & $\begin{array}{c}7 \\
(1.6)\end{array}$ & $\begin{array}{c}1 \\
(3.4)\end{array}$ & $\begin{array}{c}0 \\
(3)\end{array}$ & 8 & 1.38 \\
\hline frog & $\begin{array}{c}\text { Count } \\
\text { (expected count) }\end{array}$ & $\begin{array}{c}0 \\
(0.4)\end{array}$ & $\begin{array}{c}1 \\
(0.9)\end{array}$ & $\begin{array}{c}1 \\
(0.7)\end{array}$ & 2 & 0.34 \\
\hline hemispheric & $\begin{array}{c}\text { Count } \\
\text { (expected count) }\end{array}$ & $\begin{array}{c}0 \\
(4.3)\end{array}$ & $\begin{array}{c}21 \\
(9.4)\end{array}$ & $\begin{array}{c}1 \\
(8.3)\end{array}$ & 22 & 3.79 \\
\hline irregular & $\begin{array}{c}\text { Count } \\
\text { (expected count) }\end{array}$ & $\begin{array}{c}3 \\
(1.4)\end{array}$ & $\begin{array}{c}3 \\
(3)\end{array}$ & $\begin{array}{c}1 \\
(2.6)\end{array}$ & 7 & 1.20 \\
\hline lentoid & $\begin{array}{c}\text { Count } \\
\text { (expected count) }\end{array}$ & $\begin{array}{c}0 \\
(0.4)\end{array}$ & $\begin{array}{c}0 \\
(0.9)\end{array}$ & $\begin{array}{c}2 \\
(0.7)\end{array}$ & 2 & 0.34 \\
\hline lion & $\begin{array}{c}\text { Count } \\
\text { (expected count) }\end{array}$ & $\begin{array}{c}0 \\
(0.2) \\
\end{array}$ & $\begin{array}{c}1 \\
(0.4)\end{array}$ & $\begin{array}{c}0 \\
(0.4)\end{array}$ & 1 & 0.17 \\
\hline lion-head & $\begin{array}{c}\text { Count } \\
\text { (expected count) }\end{array}$ & $\begin{array}{c}0 \\
(0.2)\end{array}$ & $\begin{array}{c}1 \\
(0.4)\end{array}$ & $\begin{array}{c}0 \\
(0.4)\end{array}$ & 1 & 0.17 \\
\hline ovoid & $\begin{array}{c}\text { Count } \\
\text { (expected count) }\end{array}$ & $\begin{array}{c}1 \\
(4.9)\end{array}$ & $\begin{array}{c}23 \\
(10.7)\end{array}$ & $\begin{array}{c}1 \\
(9.4)\end{array}$ & 25 & 4.30 \\
\hline parallelepiped & $\begin{array}{c}\text { Count } \\
\text { (expected count) }\end{array}$ & $\begin{array}{c}0 \\
(0.4) \\
\end{array}$ & $\begin{array}{c}2 \\
(0.9) \\
\end{array}$ & $\begin{array}{c}0 \\
(0.7) \\
\end{array}$ & 2 & 0.34 \\
\hline pebble & $\begin{array}{c}\text { Count } \\
\text { (expected count) }\end{array}$ & $\begin{array}{c}0 \\
(0.4) \\
\end{array}$ & $\begin{array}{c}1 \\
(0.9) \\
\end{array}$ & $\begin{array}{c}1 \\
(0.7) \\
\end{array}$ & 2 & 0.34 \\
\hline pyramidal & $\begin{array}{c}\text { Count } \\
\text { (expected count) }\end{array}$ & $\begin{array}{c}0 \\
(0.4)\end{array}$ & $\begin{array}{c}1 \\
(0.9)\end{array}$ & $\begin{array}{c}1 \\
(0.7)\end{array}$ & 2 & 0.34 \\
\hline rectangular & $\begin{array}{c}\text { Count } \\
\text { (expected count) }\end{array}$ & $\begin{array}{c}0 \\
(0.8)\end{array}$ & $\begin{array}{c}4 \\
(1.7)\end{array}$ & $\begin{array}{c}0 \\
(1.5)\end{array}$ & 4 & 0.69 \\
\hline sphendonoid & $\begin{array}{c}\text { Count } \\
\text { (expected count) }\end{array}$ & $\begin{array}{c}94 \\
(63.4)\end{array}$ & $\begin{array}{c}91 \\
(139.2)\end{array}$ & $\begin{array}{c}141 \\
(123.4)\end{array}$ & 326 & 56.11 \\
\hline spheroid & $\begin{array}{c}\text { Count } \\
\text { (expected count) }\end{array}$ & $\begin{array}{c}1 \\
(14.6)\end{array}$ & $\begin{array}{c}68 \\
(32)\end{array}$ & $\begin{array}{c}6 \\
(28.4)\end{array}$ & 75 & 12.91 \\
\hline square & $\begin{array}{c}\text { Count } \\
\text { (expected count) }\end{array}$ & $\begin{array}{c}0 \\
(0.2)\end{array}$ & $\begin{array}{c}1 \\
(0.4)\end{array}$ & $\begin{array}{c}0 \\
(0.4)\end{array}$ & 1 & 0.17 \\
\hline stele & $\begin{array}{c}\text { Count } \\
\text { (expected count) }\end{array}$ & $\begin{array}{c}0 \\
(0.2) \\
\end{array}$ & $\begin{array}{c}0 \\
(0.4) \\
\end{array}$ & $\begin{array}{c}1 \\
(0.4) \\
\end{array}$ & 1 & 0.17 \\
\hline Truncated-cone & $\begin{array}{c}\text { Count } \\
\text { (expected count) }\end{array}$ & $\begin{array}{c}0 \\
(0.4)\end{array}$ & $\begin{array}{c}1 \\
(0.8)\end{array}$ & $\begin{array}{c}1 \\
(0.8)\end{array}$ & 2 & 0.34 \\
\hline Total & & 113 & 248 & 220 & 581 & 100 \\
\hline
\end{tabular}


Table 2. Shapes of Middle Bronze Age balance weights tabulated against their distribution zones. The two sets of values show the observed number of weights divided per shape in each region ("count") compared with their expected count in case they were randomly distributed. A chi-squared test ( $\mathrm{p}$ value $<0.001)$ reveals that the shapes of balance weights are significantly associated with their distribution zones.

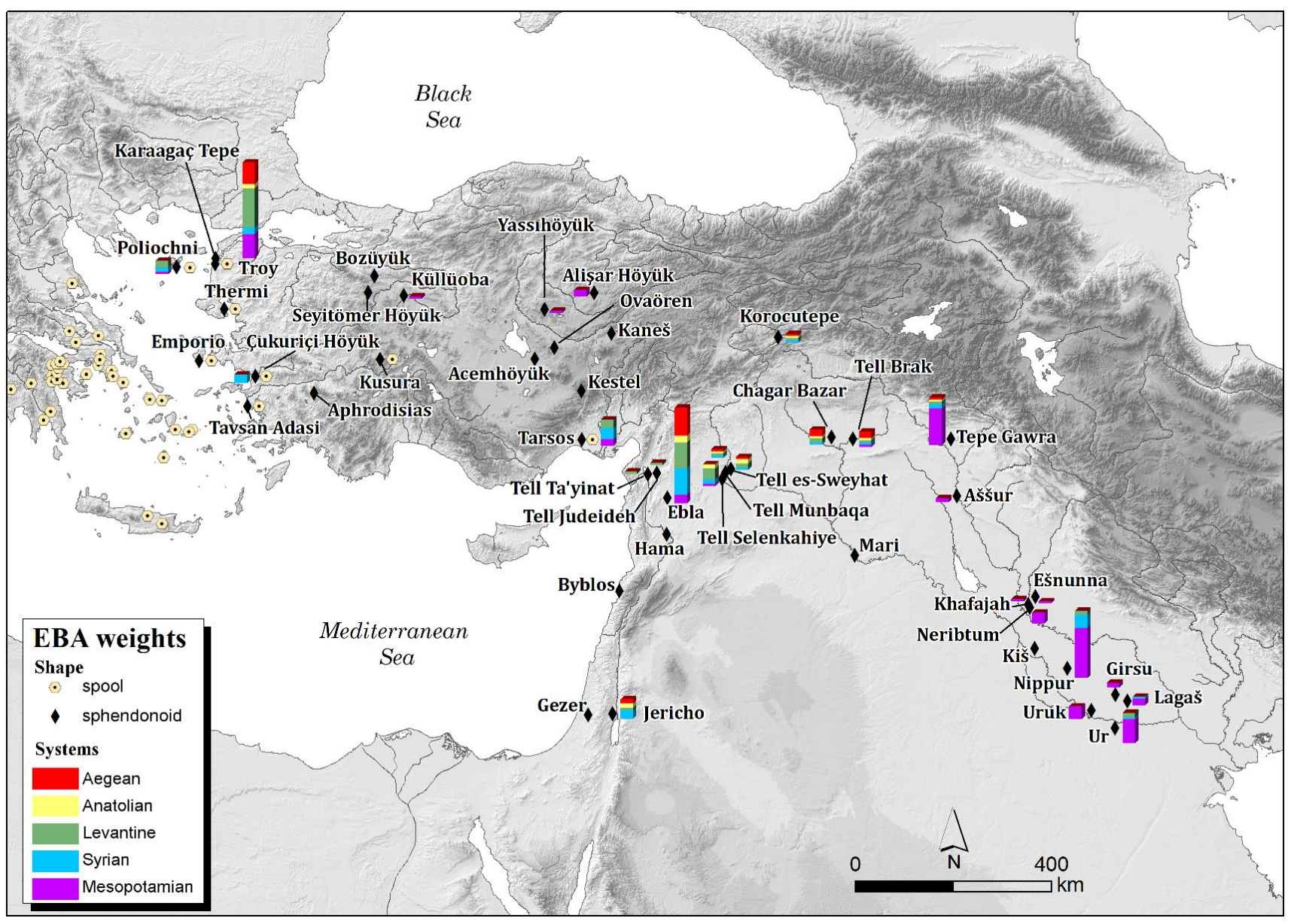

Figure 2. Map showing the distribution of different Early Bronze Age weight systems. 


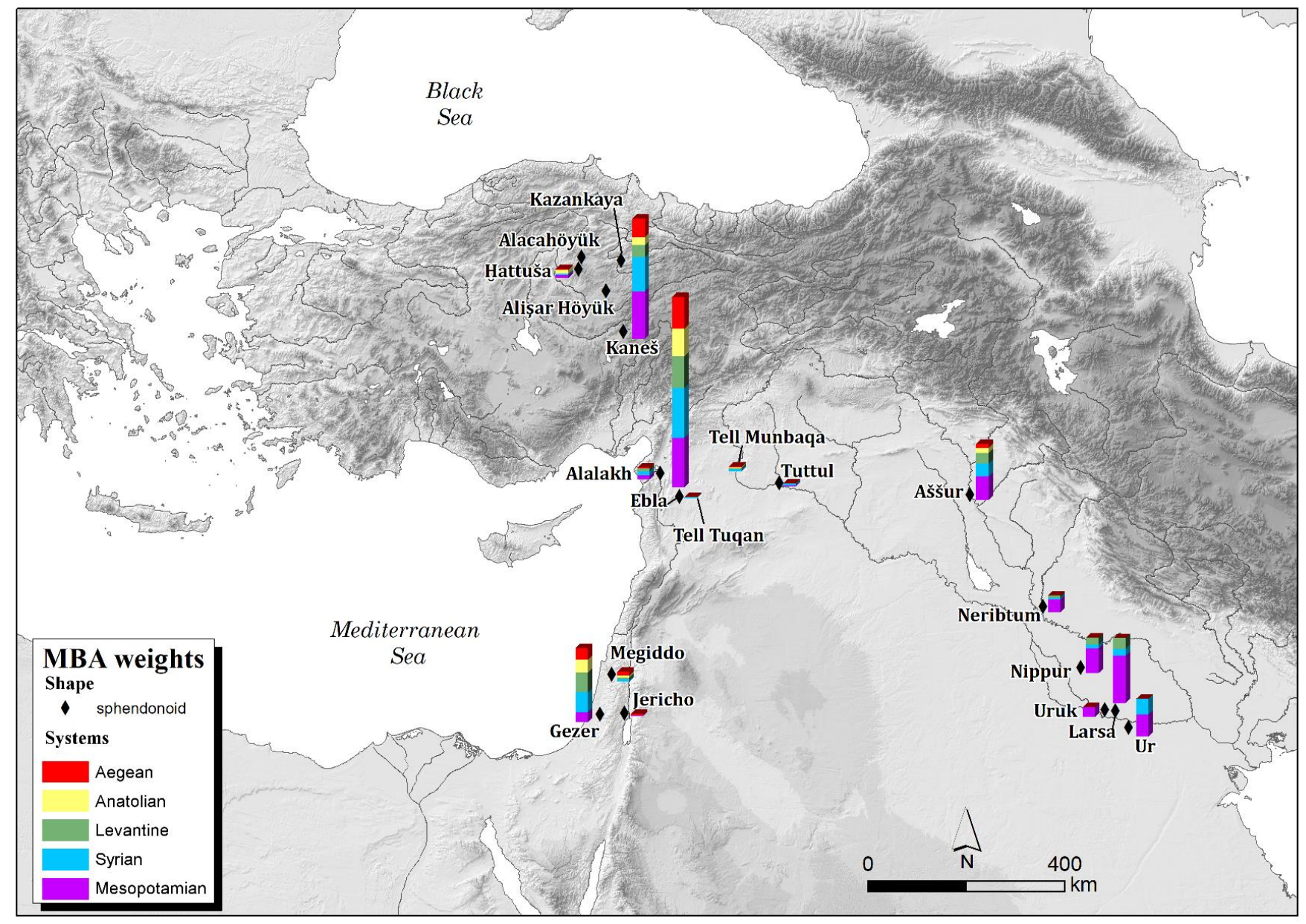

Figure 3. Map showing the distribution of different Middle Bronze Age weight systems.

\begin{tabular}{|c|c|c|c|c|c|c|}
\hline \multicolumn{2}{|c|}{ Weight System } & \multicolumn{5}{c|}{ Regions } \\
\cline { 3 - 6 } \multicolumn{2}{c|}{} & & & \multicolumn{2}{c|}{ Mesopotamia } & \\
\cline { 3 - 6 } & & & Upper & Lower & \\
\hline \multirow{2}{*}{ Aegean } & Count & 11 & 15 & 9 & 0 & 35 \\
& (expected count) & $(9.9)$ & $(7.7)$ & $(8)$ & $(9.3)$ & \\
\hline Anatolian & $\begin{array}{c}\text { Count } \\
\text { (expected count) }\end{array}$ & 3 & 3 & 8 & 0 & 14 \\
& $\begin{array}{c}\text { Count } \\
\text { Levantine }\end{array}$ & 24 & $(3.1)$ & $(3.2)$ & $(3.7)$ & \\
& (expected count) & $(15.9)$ & $(12.4)$ & $(12.8)$ & $(14.9)$ & 56 \\
\hline Syrian & Count & 14 & 16 & 5 & 8 & 43 \\
& (expected count) & $(12.2)$ & $(9.5)$ & $(9.9)$ & $(11.5)$ & \\
\hline Mesopotamian & Count & 16 & 4 & 20 & 52 & 92 \\
& (expected count) & $(26.1)$ & $(20.3)$ & $(21.1)$ & $(24.5)$ & \\
\hline & Total & 68 & 66 & 55 & 64 & 240 \\
\hline
\end{tabular}

Table 3. Cross-tabulation of Early Bronze Age "Weight System" and "Regions" variables. The two sets of values show the observed number of weight systems in each region ("count") compared with their expected count in case they were randomly distributed. A chi-squared test (p-value $<0.001$ ) reveals that the EBA weight systems are significantly associated with their distribution zones. 


\begin{tabular}{|c|c|c|c|c|c|c|}
\hline \multicolumn{2}{|c|}{ Weight System } & \multicolumn{5}{|c|}{ Regions } \\
\hline & & & & \multicolumn{2}{|c|}{ Mesopotamia } & \\
\hline & & & & Upper & Lower & \\
\hline Aegean & $\begin{array}{c}\text { Count } \\
\text { (expected count) }\end{array}$ & $\begin{array}{c}21 \\
(15.4)\end{array}$ & $\begin{array}{c}50 \\
(33.8)\end{array}$ & $\begin{array}{c}5 \\
(7.5)\end{array}$ & $\begin{array}{c}0 \\
(19.3)\end{array}$ & 76 \\
\hline Anatolian & $\begin{array}{c}\text { Count } \\
\text { (expected count) }\end{array}$ & $\begin{array}{c}13 \\
(12.5)\end{array}$ & $\begin{array}{c}43 \\
(27.6)\end{array}$ & $\begin{array}{c}6 \\
(6.1)\end{array}$ & $\begin{array}{c}0 \\
(15.7)\end{array}$ & 62 \\
\hline Levantine & $\begin{array}{c}\text { Count } \\
\text { (expected count) }\end{array}$ & $\begin{array}{c}12 \\
(20.4)\end{array}$ & $\begin{array}{c}57 \\
(45)\end{array}$ & $\begin{array}{c}12 \\
(10)\end{array}$ & $\begin{array}{c}20 \\
(25.6)\end{array}$ & 101 \\
\hline Syrian & $\begin{array}{c}\text { Count } \\
\text { (expected count) }\end{array}$ & $\begin{array}{c}36 \\
(32.3)\end{array}$ & $\begin{array}{c}78 \\
(71.2)\end{array}$ & $\begin{array}{c}17 \\
(15.8)\end{array}$ & $\begin{array}{c}29 \\
(40.6)\end{array}$ & 160 \\
\hline Mesopotamian & $\begin{array}{c}\text { Count } \\
\text { (expected count) }\end{array}$ & $\begin{array}{c}51 \\
(52.4) \\
\end{array}$ & $\begin{array}{c}65 \\
(115.3) \\
\end{array}$ & $\begin{array}{c}25 \\
(25.6) \\
\end{array}$ & $\begin{array}{c}118 \\
(65.7)\end{array}$ & 249 \\
\hline & Total & 133 & 293 & 65 & 167 & 658 \\
\hline
\end{tabular}

Table 4. Cross-tabulation of Middle Bronze Age "Weight System" and "Regions" variables. The two sets of values show the observed number of weight systems in each region ("count") compared with their expected count in case they were randomly distributed. A chi-squared test (p-value <0.001) reveals that the MBA weight systems are significantly associated with their distribution zones. 
EBA regions

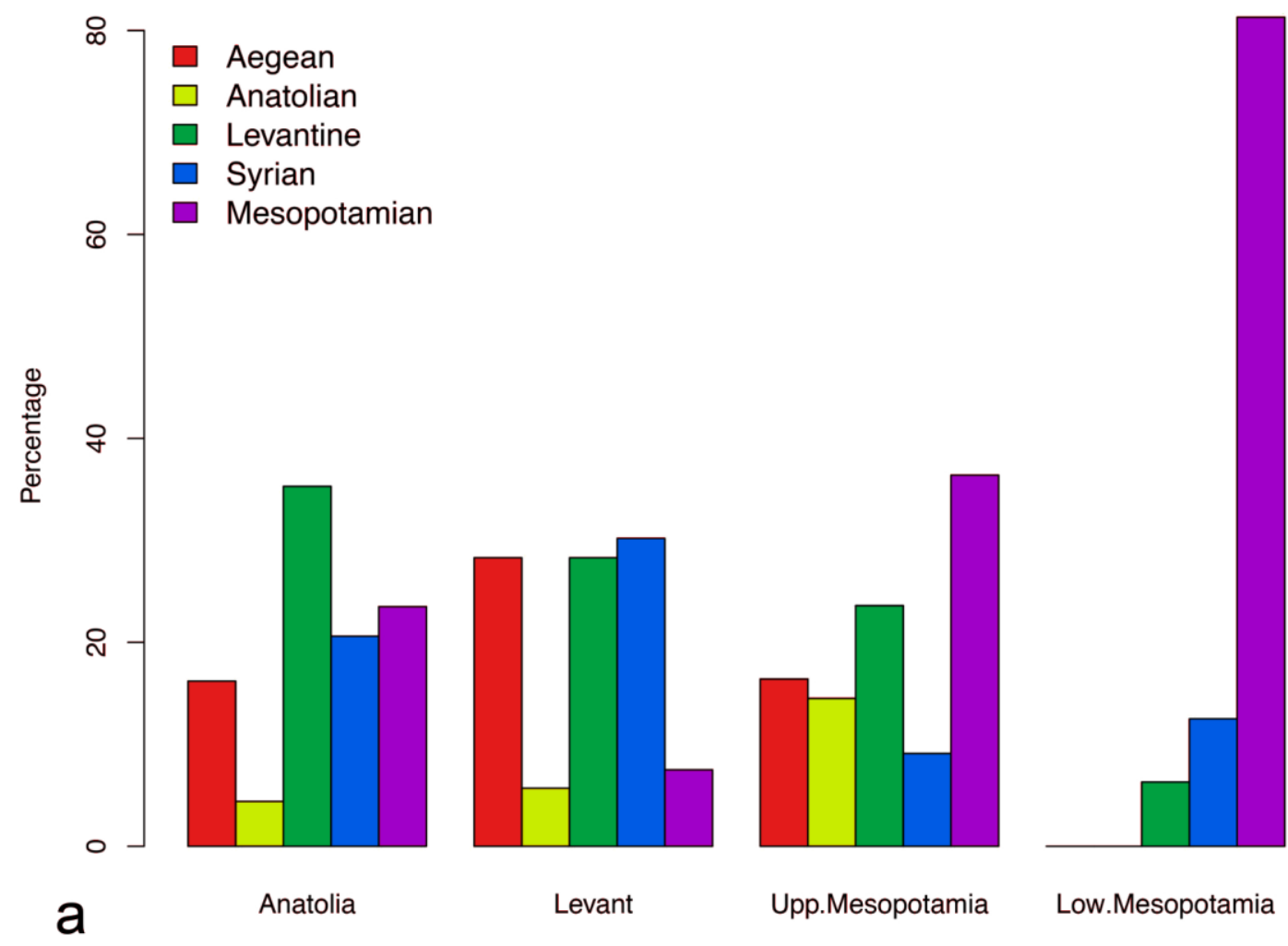

MBA regions

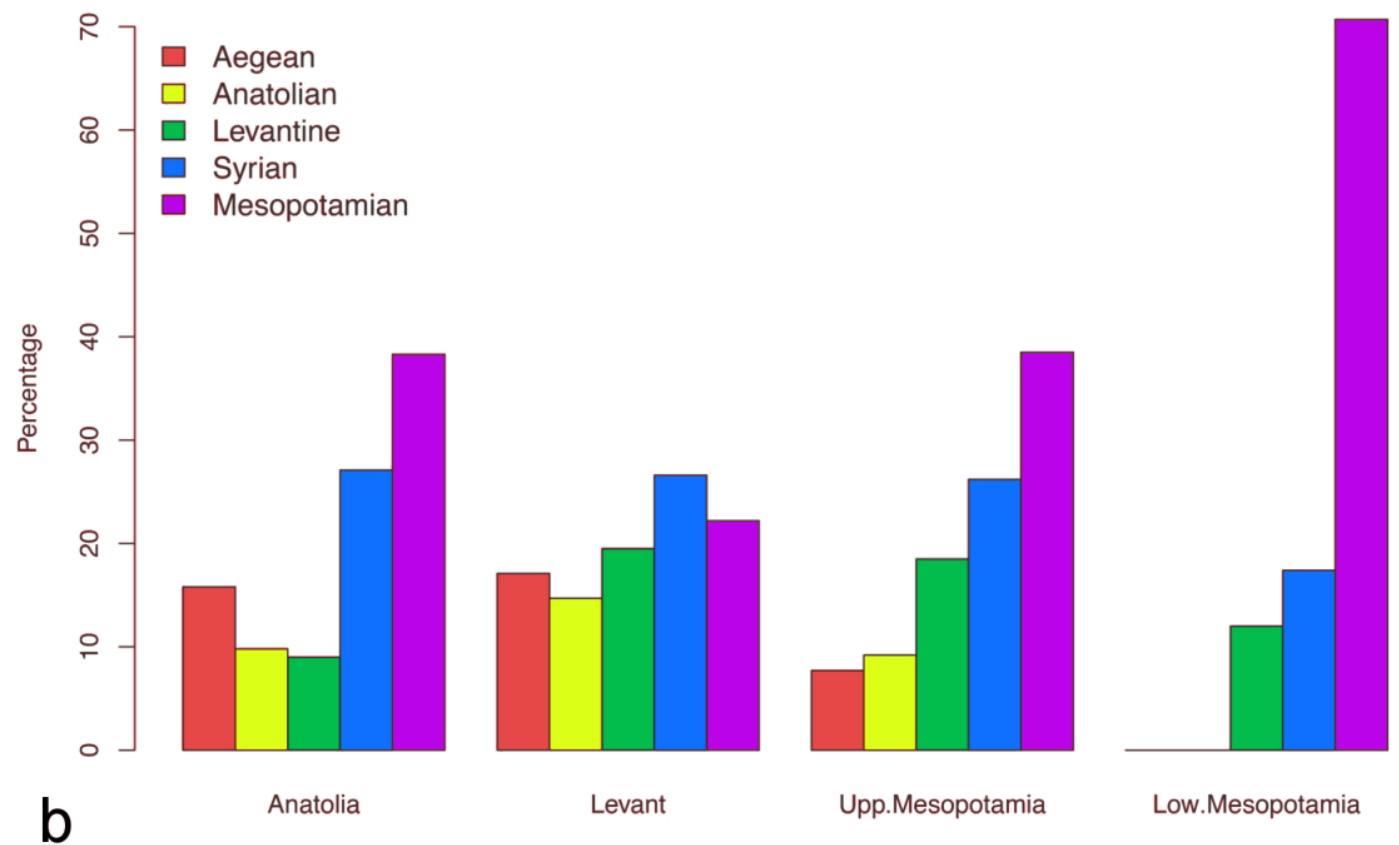

Figure 4. Histograms showing the proportion of different weight systems in the Early Bronze Age (a) and Middle Bronze Age (b), divided according to the main geo-cultural regions. 


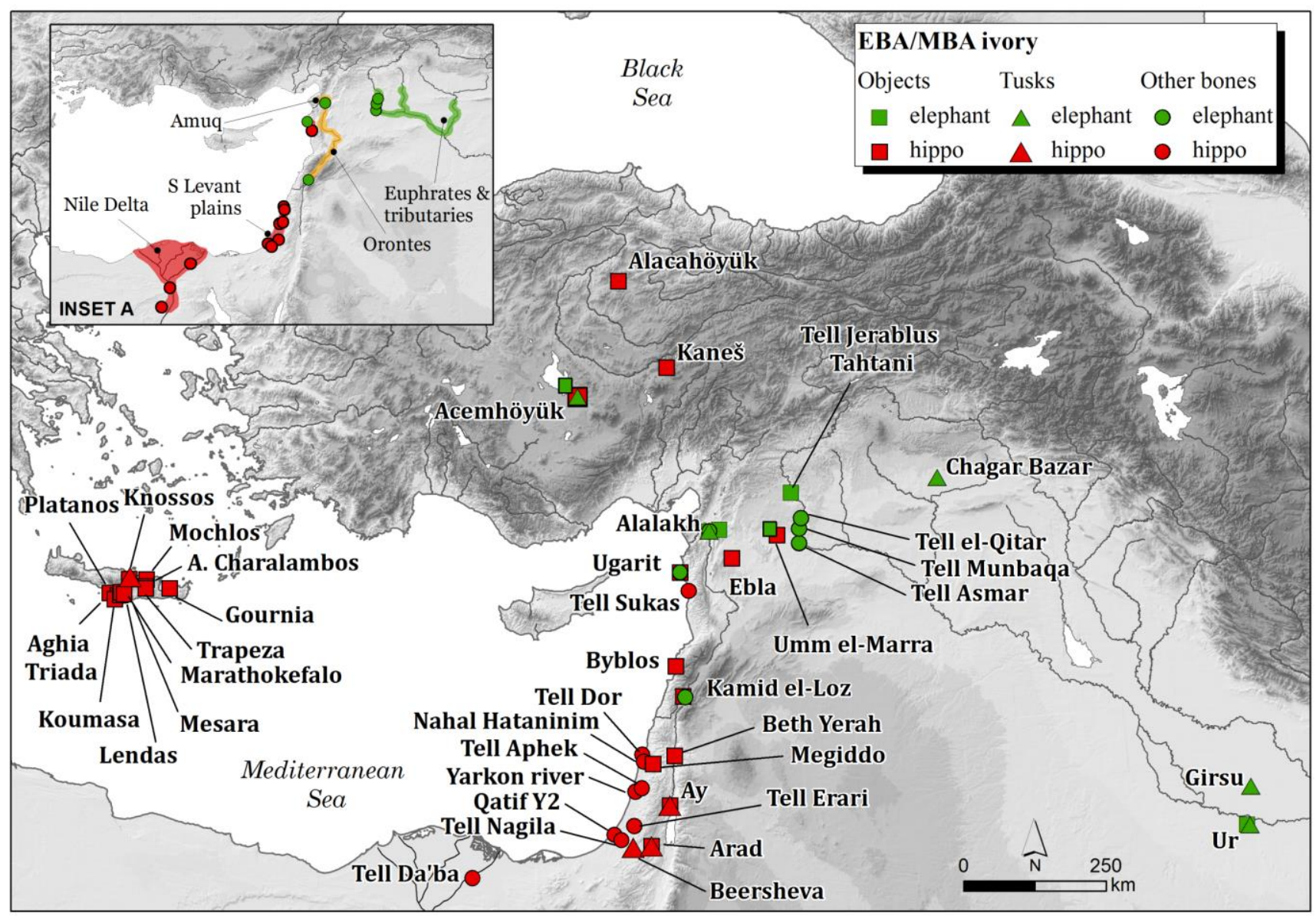

Figure 5. Map of Early Bronze Age and Middle Bronze Age ivory objects, elephant/hippopotamus tusks and other skeletal remains for which a specialist assessment on the animal species is available. Inset (a) shows the distribution of Early Bronze Age and Middle Bronze Age skeletal remains of hippopotamus (red) and elephant (green), together with the suggested habitat areas of these species: Nile Delta (hippo), southern Levant coastal plains (hippo), the Orontes and Amuq valleys (hippo and elephant), the Euphrates basin (elephant). 


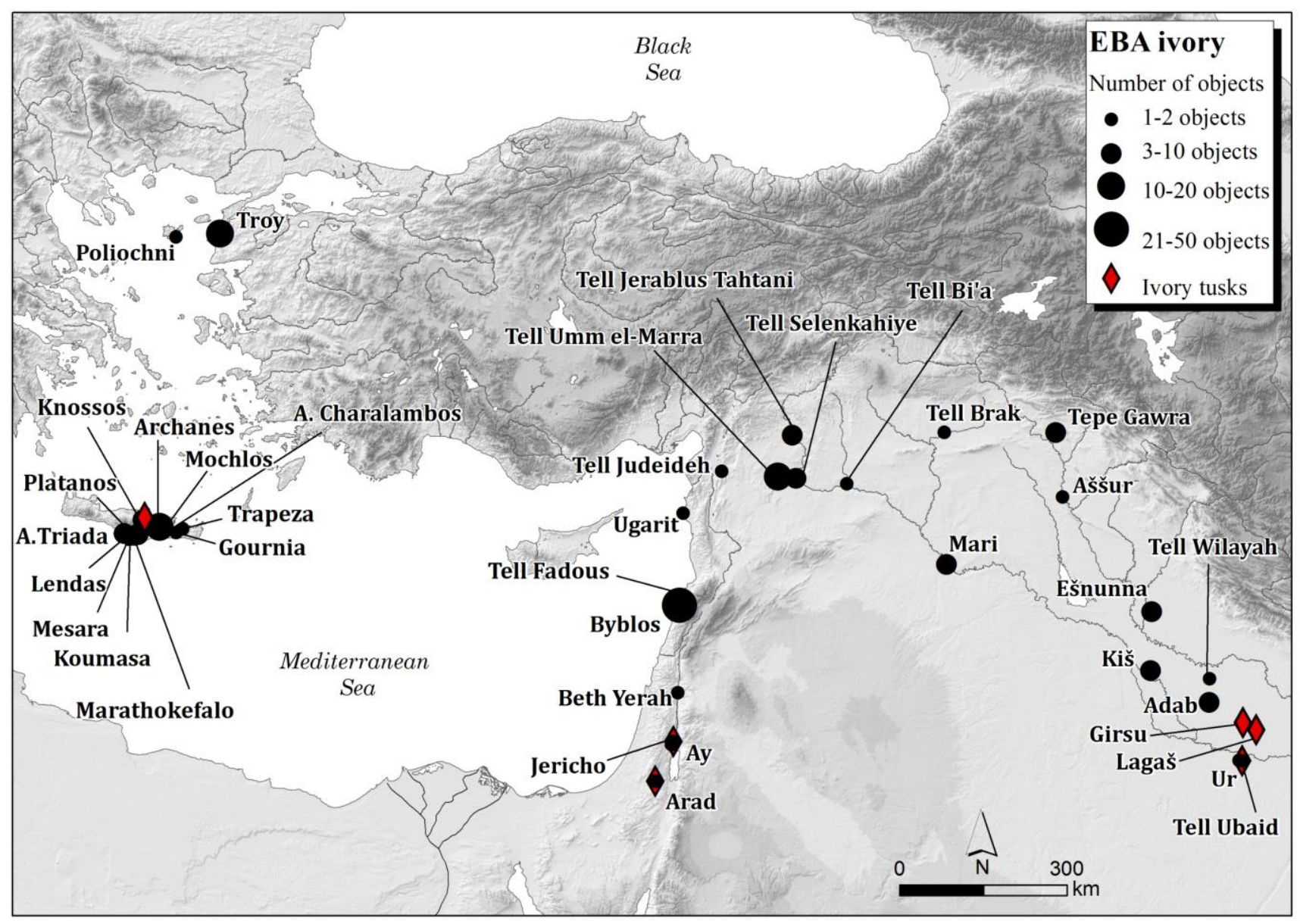

Figure 6. Distribution of ivory products and ivory tusks during the Early Bronze Age period. 


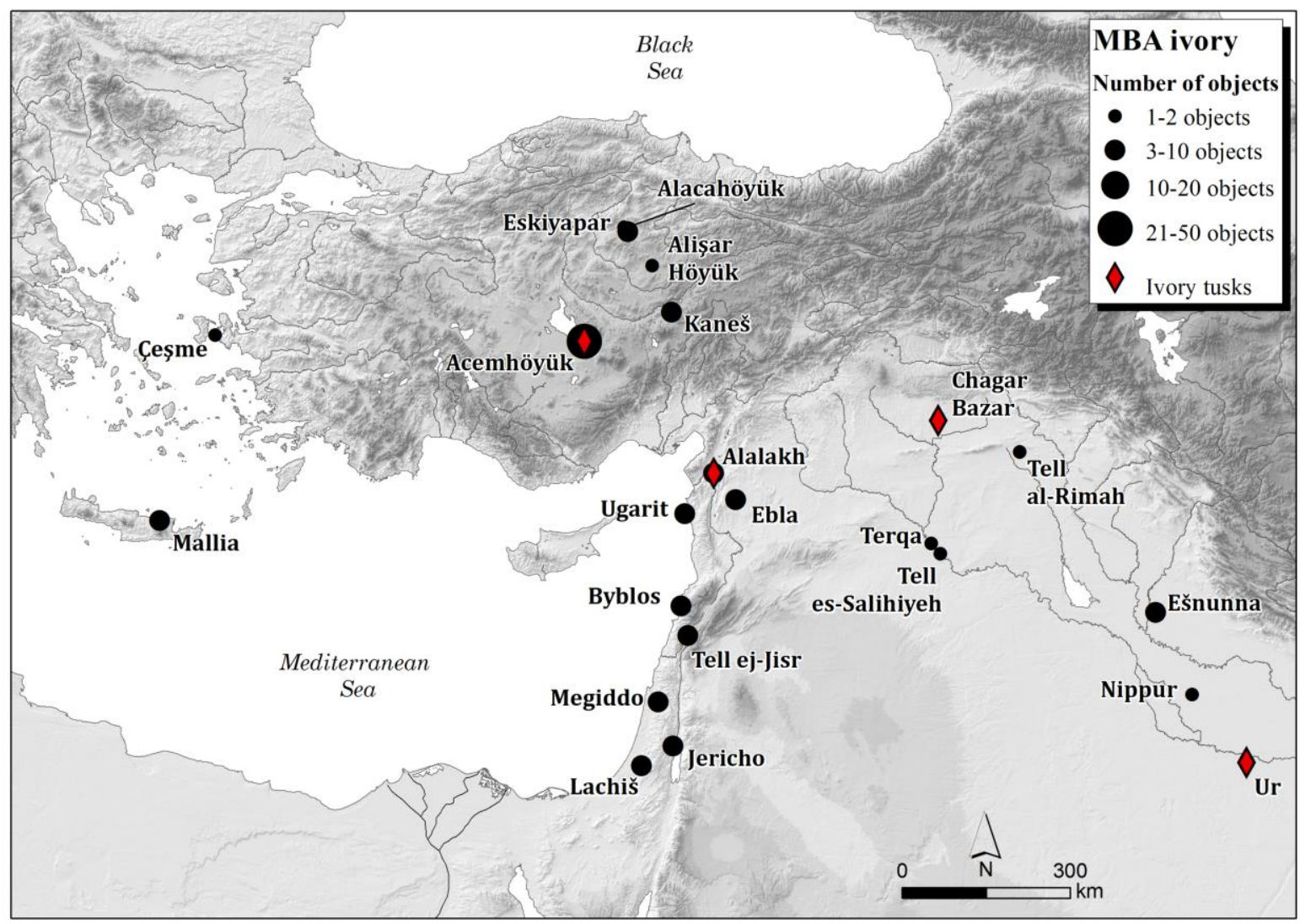

Figure 7. Distribution of ivory products and ivory tusks during the Middle Bronze Age period.

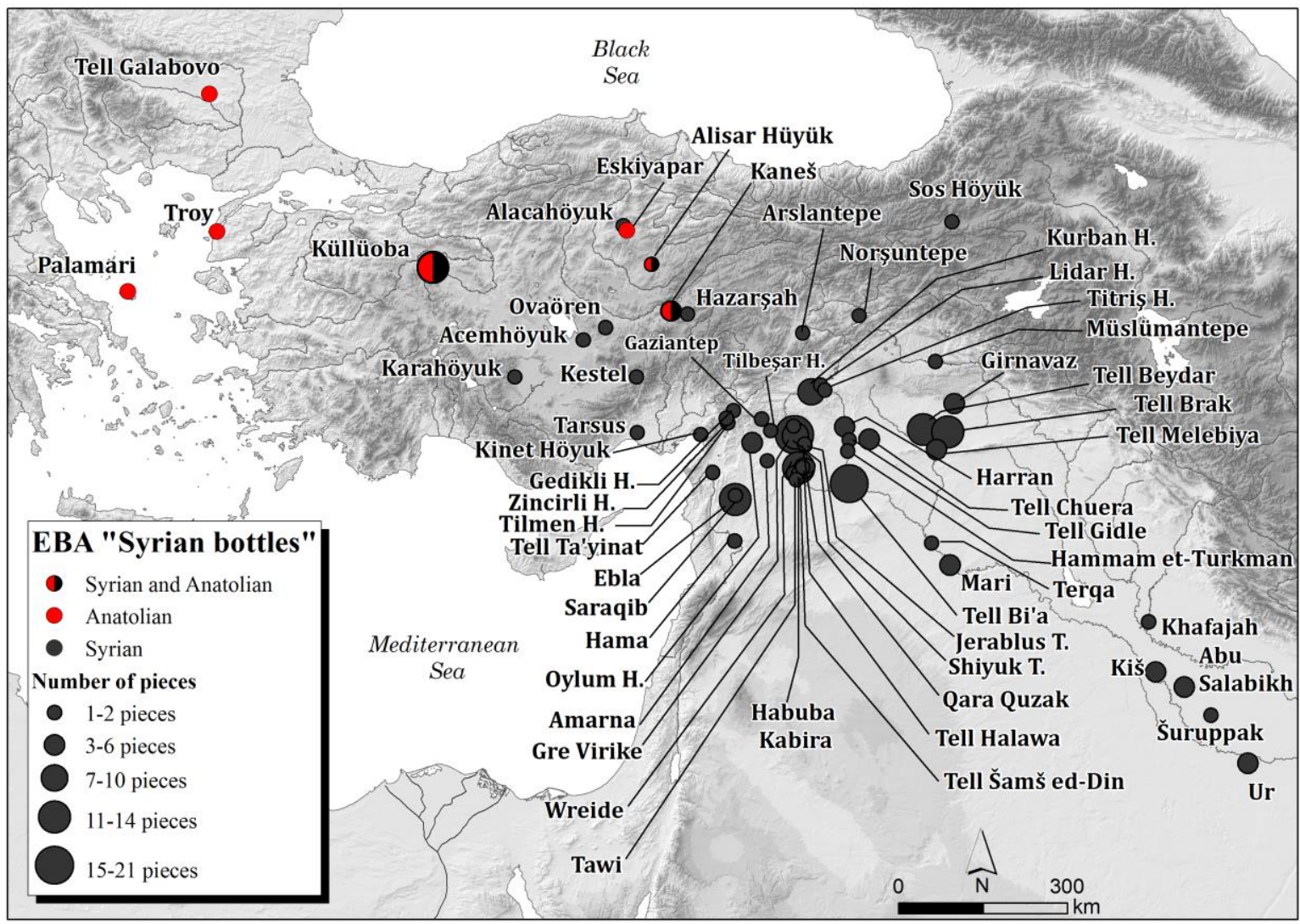

Figure 8. Map showing the distribution of Syrian Bottles during the Early Bronze Age period. 


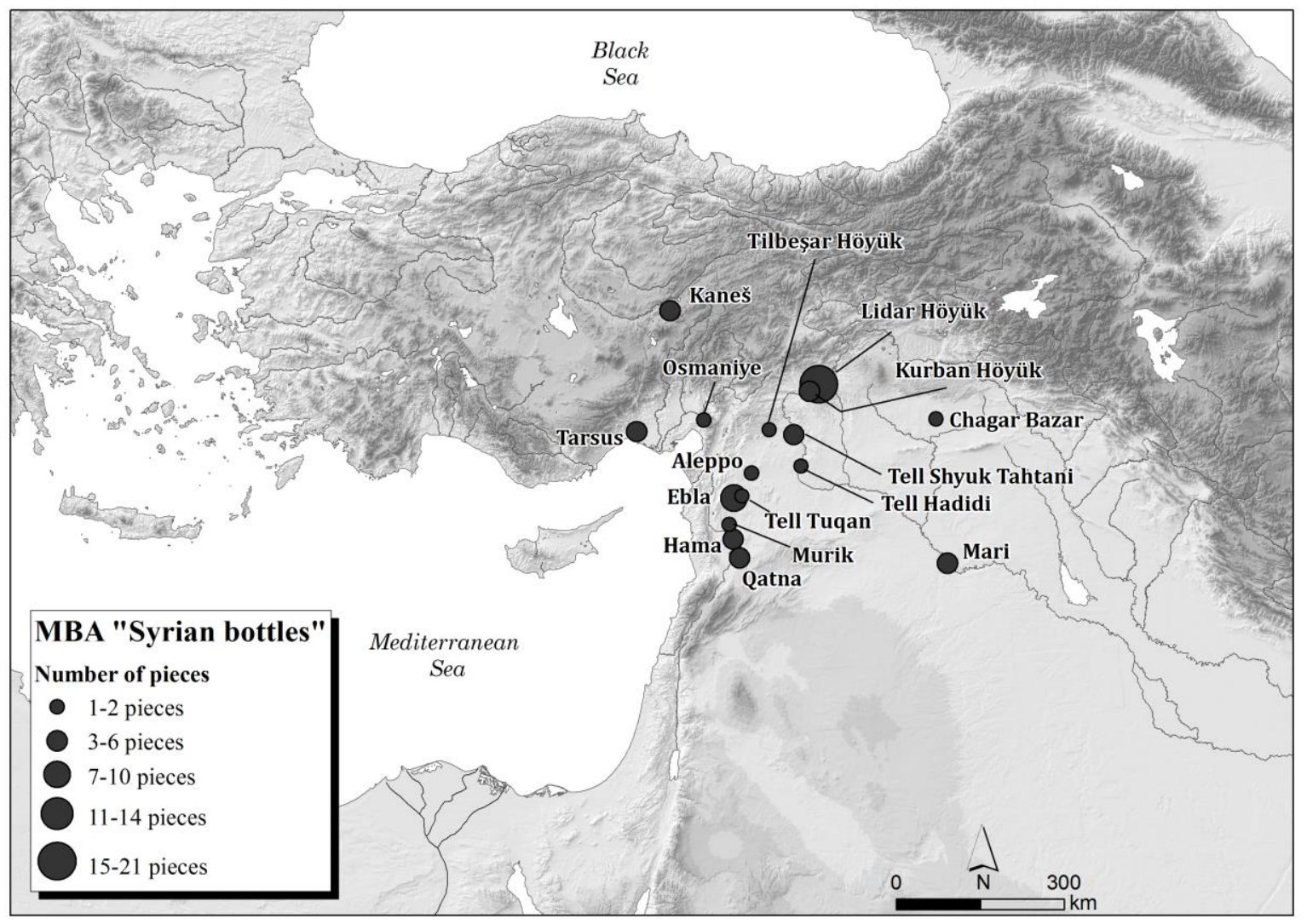

Figure 9. Map showing the distribution of Syrian Bottles during the Middle Bronze Age period.

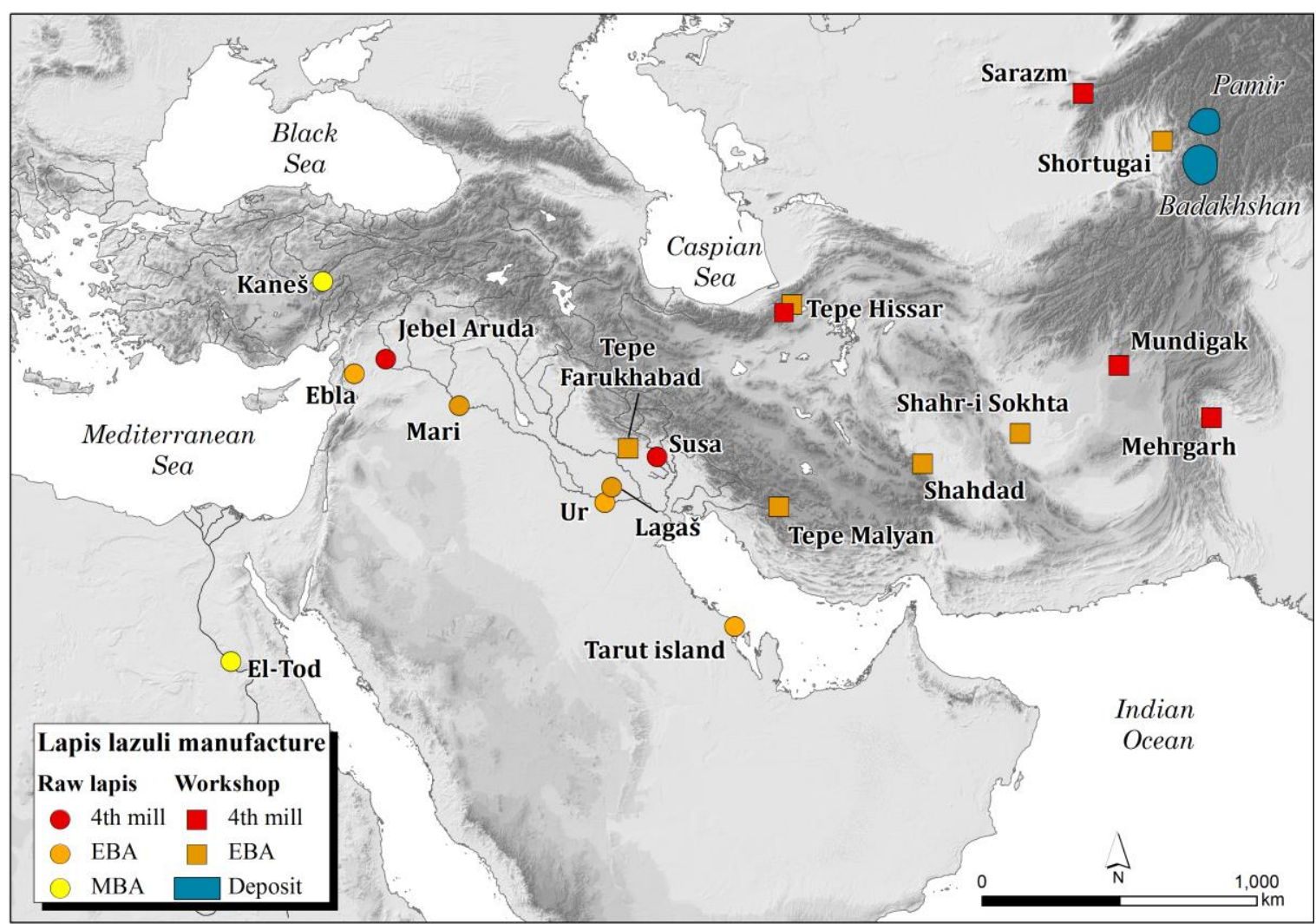

Figure 10. Map showing the location of the Badakhshan and Pamir lapis lazuli deposits, and distribution of the evidence for lapis lazuli manufacture in the Near and Middle East, between the fourth and early second millennia BC. 


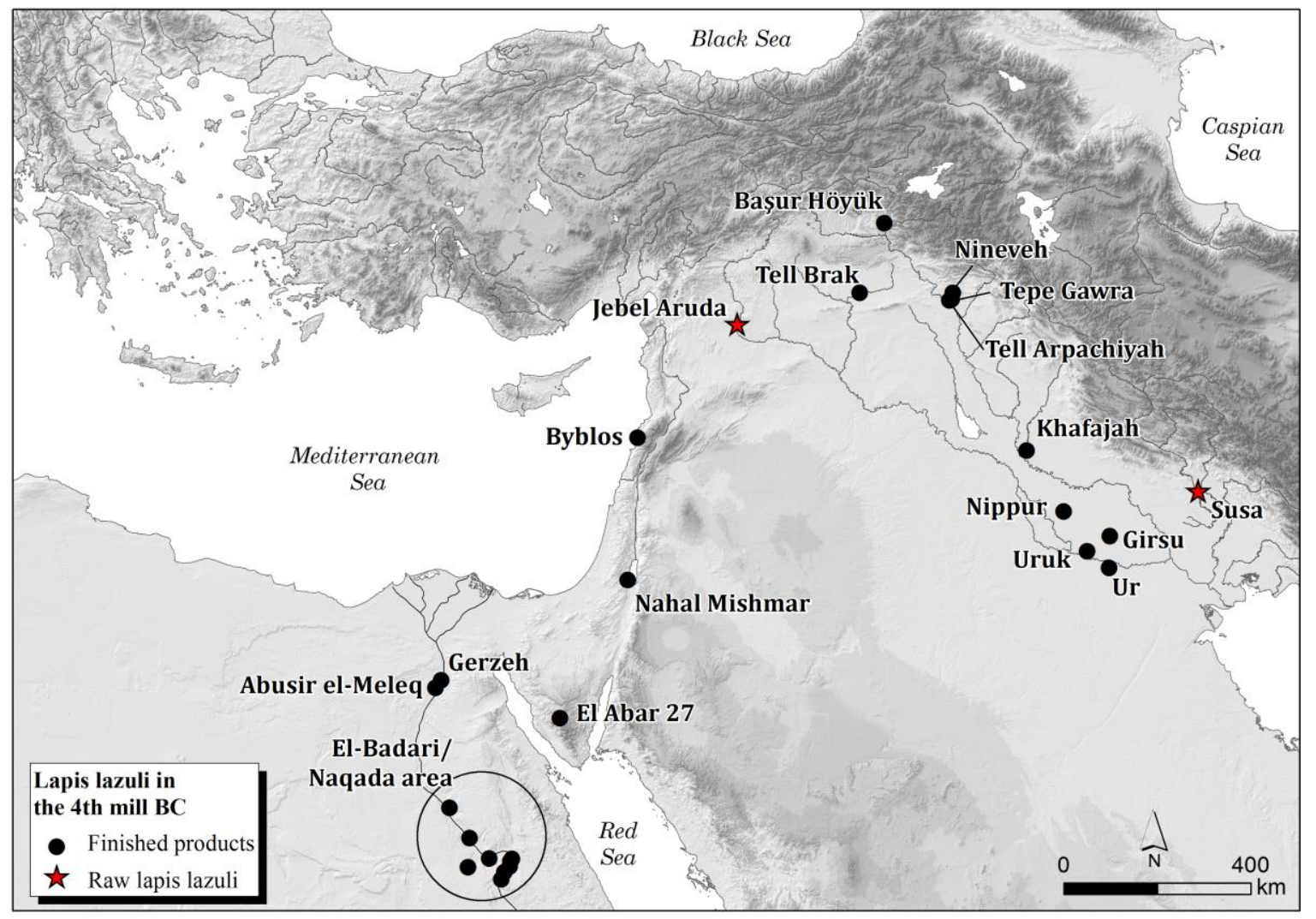

Figure 11. Map showing the distribution of raw lapis lazuli finds and finished lapis lazuli products in the Near East and Egypt, during the fourth millennium BC.

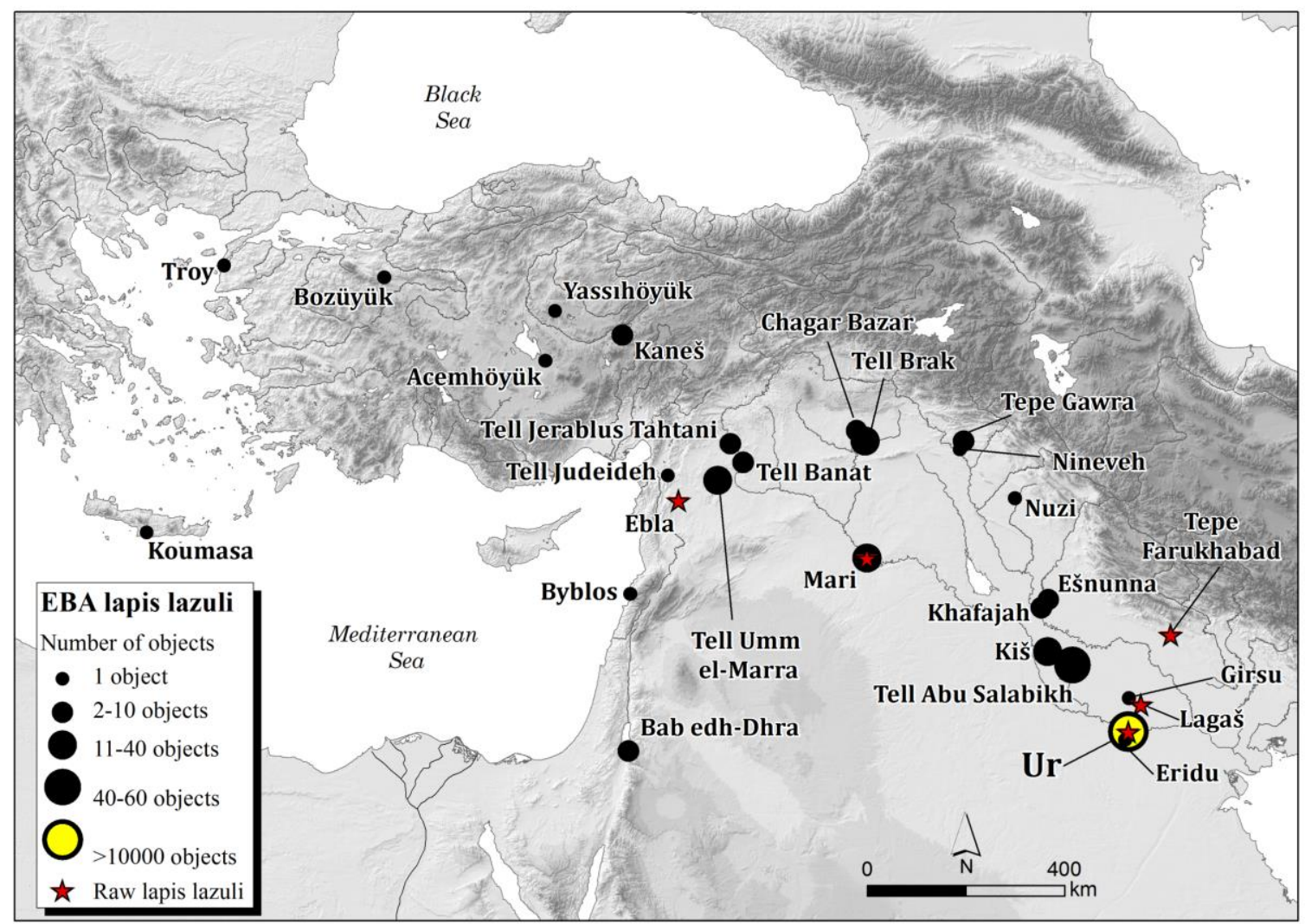

Figure 12. Distribution of raw lapis lazuli finds (both from archaeological evidence and textual sources) and finished lapis lazuli products in the Near East, during the Early Bronze Age period. 


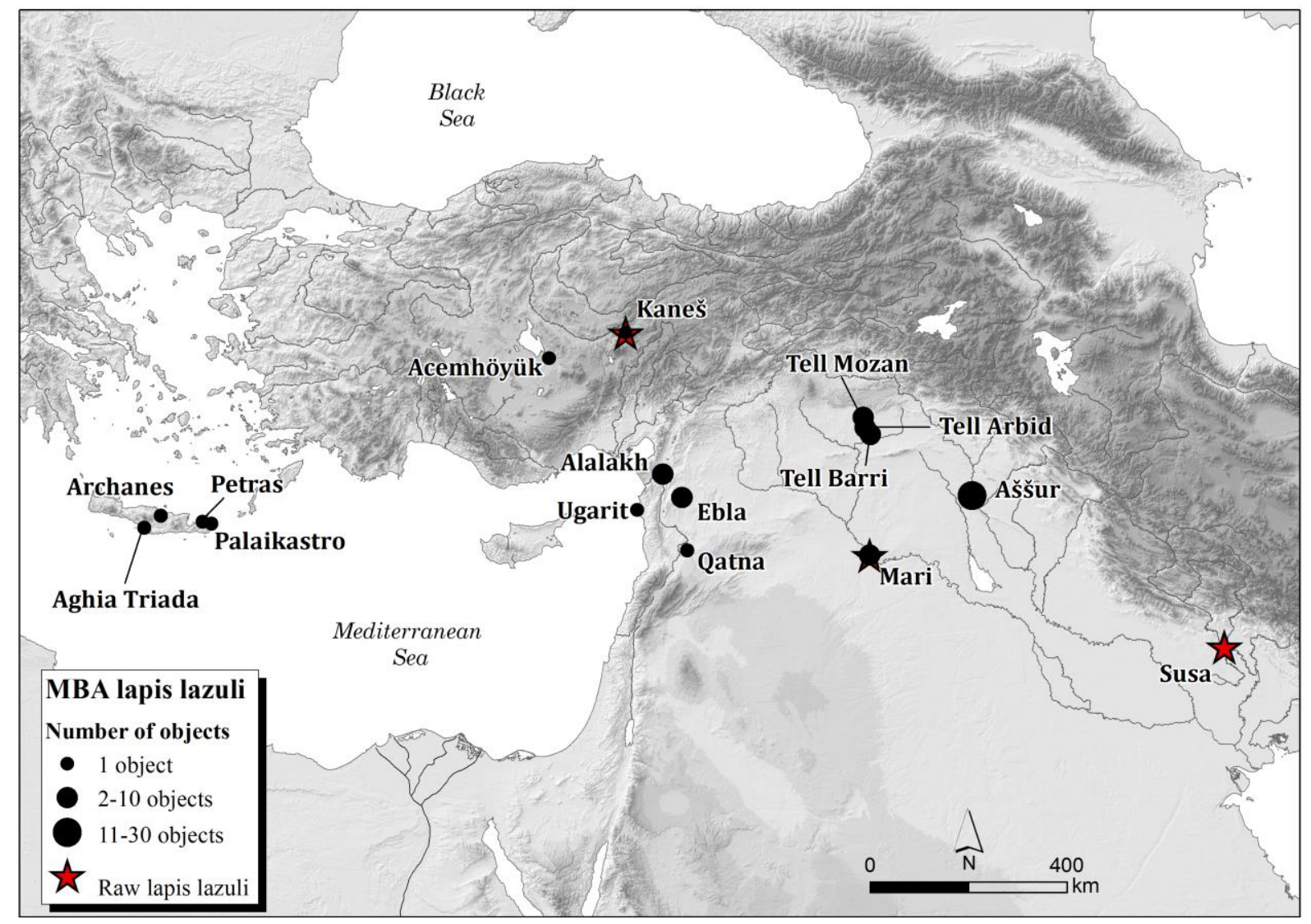

Figure 13. Distribution of raw lapis lazuli finds (both from archaeological evidence and textual sources) and finished lapis lazuli products in the Near East, during the Middle Bronze Age period.

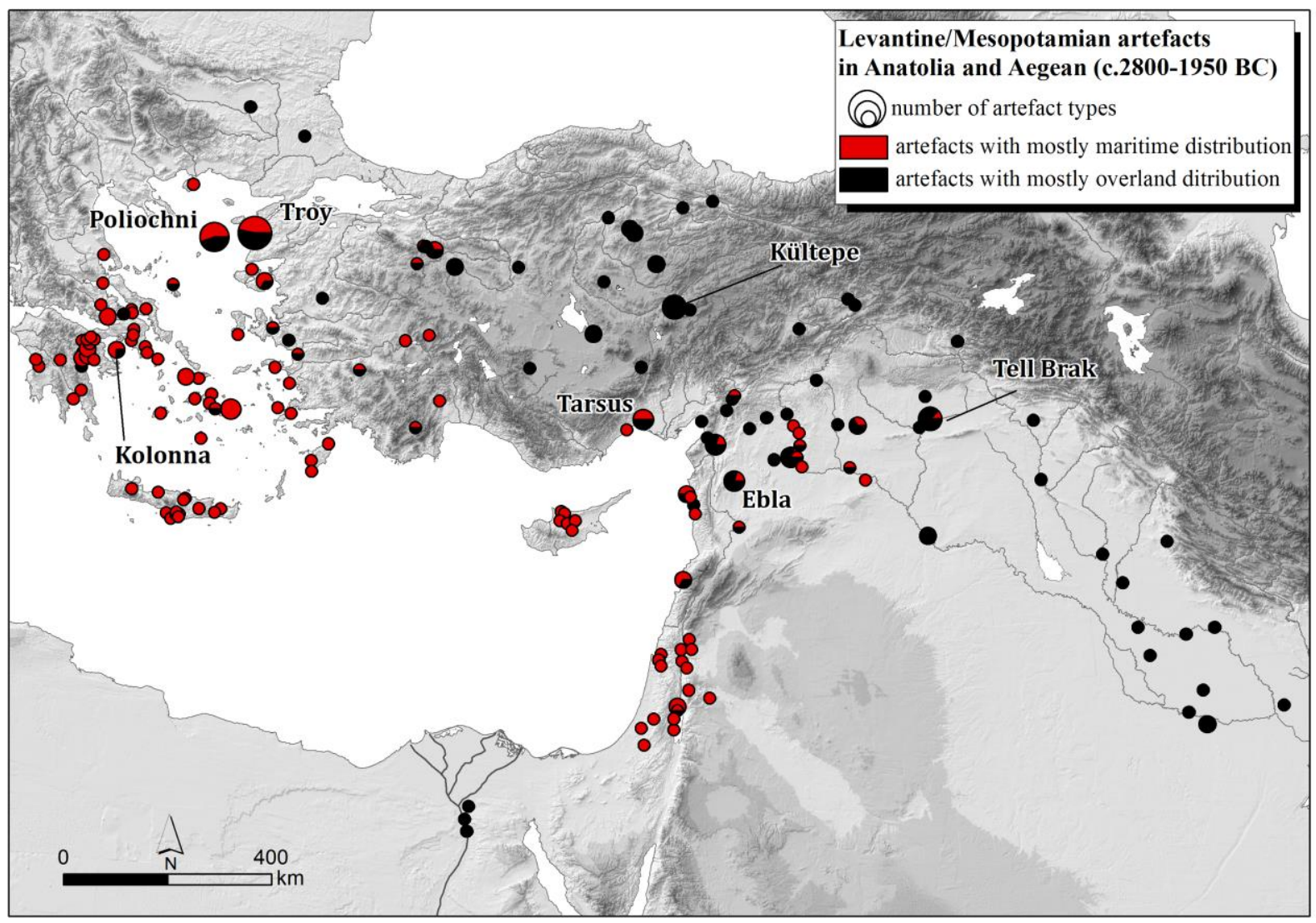


Figure 14. Map of sites involved in the Early Bronze Age interregional networks between Aegean, Anatolia, Levant and Mesopotamia, with at least one artefact type considered as a marker for longdistance trade. Different symbol sizes reflect the number of artefacts identified at each site; artefacts that have mainly a maritime circulation are marked in red, while artefacts with mainly overland circulation are marked in black. To note that northern Levant and northern Mesopotamia emerge as the area with the highest proportion of goods from both networks. Map from Massa 2016, Fig.7.69.

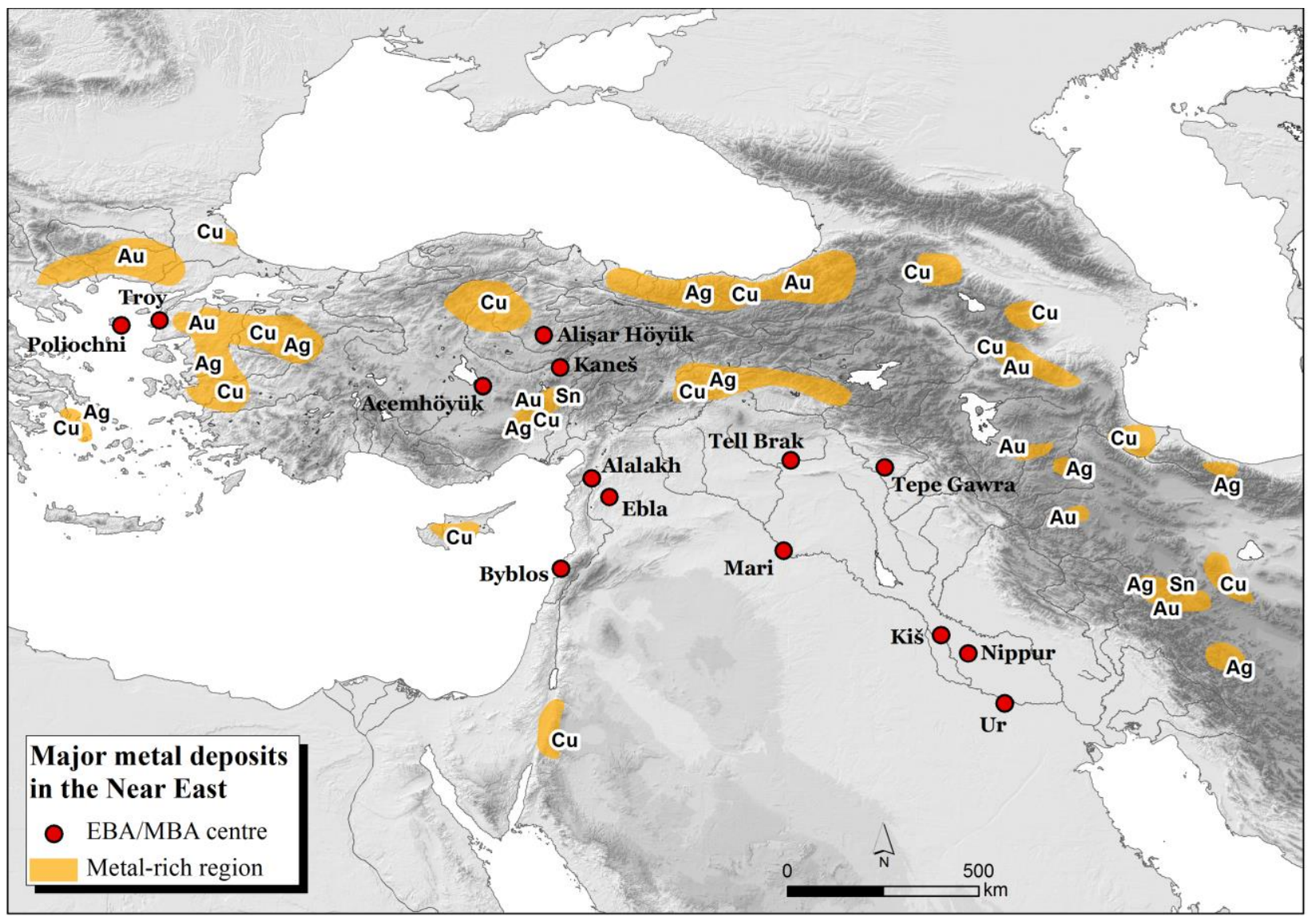

Figure 15. Location of metal-rich regions across the Near East, compared to the location of major Early and Middle Bronze Age centres. Also indicated are the main metal deposits present in each area $(\mathrm{Au}=$ gold, $\mathrm{Ag}=$ silver, $\mathrm{Cu}=$ copper, $\mathrm{Sn}=$ tin). Data on metal deposits from Massa 2016, Fig.6.33; Wilkinson 2014, Figs.5.1, 5.4, 5.7, 5.8. 


\section{Bibliography}

al-Besso, M., 2015. Analyse préliminaire d'un atelier de production d'objets en os à Tell Sakka (Bronze Moyen, Syrie du Sud) in: Pfälzner, P., al-Maqdissi, M. (Eds.), Qatna and the Networks of Bronze Age Globalism: Proceedings of an International Conference in Stuttgart and Tübingen in October 2009. Harassowitz, Wiesbaden, pp. 111-116.

Alberti, M.E., 2012. Aegean trade systems: Overview and observations on the Middle Bronze Age, in: Alberti, M.E., Sabatini, S. (Eds.), Exchange Networks and Local Transformations: Interaction and local change in Europe and the Mediterranean from the Bronze Age to the Iron Age. Oxbow, Oxford, pp. 22-43.

Alberti, M.E., Ascalone, E., Peyronel, L., 2006. Weights in context. Bronze Age weighing systems of Eastern Mediterranean: chronology, typology, material and archaeological contexts. Proceedings of the International Colloquium, Rome 22nd-24th November 2004. Istituto Italiano di Numismatica, Roma.

Algaze, G., 1993. The Uruk world system: the dynamics of expansion of early Mesopotamian civilization. University of Chicago Press, Chicago.

Antonova, I., Tolstikov, V., Treister, M., 1996. The Gold of Troy: Searching for Homer's Fabled City. Thames \& Hudson, London.

Apakidze, J., 1999. Lapislazuli-funde des 3. un 2. Jahrtausends v.Chr. in der Kaukasusregion - Ein Beitrag zur Hefkunft des Lapislazuli in Troia. Studia Troica 9, 511-525.

Arbuckle, B.S., 2013. Zooarchaeology at Acemhöyük. Anadolu 39, 55-68.

Archi, A., 2013. History of Syria in the Third Millennium: the Written Sources, in: Orthmann, W., Matthiae, P., al-Maqdissi, M. (Eds.), Archéologie et Histoire de la Syrie I: La Syrie de l'époque néolithique à l'âge du fer. Harrassowitz, Wiesbaden, pp. 75-88.

Archi, A., Biga, M.G., 2003. A Victory over Mari and the Fall of Ebla. Journal of Cuneiform Studies 55, 1-44.

Aruz, J., Benzel, K., Evans, J., 2008. Beyond Babylon: Art, Trade, and Diplomacy in the Second Millennium B.C. The Metropolitan Museum of Art, New York.

Aruz, J., Wallenfels, R., 2003. Art of the First Cities: The Third Millennium B.C. from the Mediterranean to the Indus. The Metropolitan Museum, New York.

Ascalone, E., Peyronel, L., 2000. “... secondo la norma del peso del re”. Alalakh e Mari: contesti archeologici palatini e sistemi ponderali in Siria durante la media età del Bronzo. Quaderni Ticinesi di Numismatica e Antichità Classiche 29, 7-45.

Ascalone, E., Peyronel, L., 2006. I Pesi da bilancia dell'età del Bronzo Antico e Medio. Universita' di Roma "La Sapienza", Roma.

Atıc1, L., 2003. Early Bronze Age fauna from Kaman Kalehöyük (central Turkey): a preliminary analysis. Anatolian Archaeological Studies XII, 99-102.

Atıc1, L., 2005. Centralized or Decentralized: The Mode of Pastoral Economy at Early Bronze Age Kaman-Kalehöyük. Anatolian Archaeological Studies XIV, 119-127. 
Atıc1, L., 2014. Food and Ethnicity at Kültepe/Kanesh: Preliminary Zooarchaeological Evidence, in: Atıcı, L., Kulakoğlu, F., Barjamovic, G., Fairbairn, A. (Eds.), Current research at Kültepe/Kanesh: an Interdisciplinary and Integrative Approach to Trade Networks, Internationalism, and Identity. Lockwood Press, Atlanta, pp. 195-211.

Atıc1, L., Kulakoğlu, F., Barjamovic, G., Fairbairn, A., 2014. Current Research at KültepeKanesh: An Interdisciplinary and Integrative Approach to Trade Networks, Internationalism, and Identity. Lockwood Press, Atlanta.

Aubet, M.E., 2013. Commerce and Colonization in the Ancient Near East. Cambridge University Press, Cambridge.

Ay, E., Kibaroğlu, M., Berthold, C., 2014. A multi-analytical approach to characterize an Early Bronze Age cosmetic material from Müslümantepe, Southeastern Anatolia. Archaeological and Anthropological Sciences 6, 125-131.

Bachhuber, C., 2012. Sumer, Akkad, Ebla and Anatolia, in: Crawford, H. (Ed.), The Sumerian World. Routledge, London, pp. 498-516.

Bachhuber, C., 2015. Citadel and Cemetery in Early Bronze Age Anatolia. Equinox, London.

Baird, D., Asouti, E., Astruc, L., Baysal, A., Baysal, E., Carruthers, D., Fairbairn, A., Kabukçu, C., Jenkins, E., Lorentz, K., Middleton, C., Pearson, J., Pirie, A., 2013. Juniper smoke, skulls and wolves' tails. The Epipalaeolithic of the Anatolian plateau in its SW Asian context; insights from Pınarbaşı. Levant 45, 175-209.

Bar-Yosef Mayer, D.E., Porat, N., Davidovich, U., 2014. Personal Ornaments at the Nahal Mishmar Cave of the Treasure. Near Eastern Archaeology 77, 266-273.

Barjamovic, G., 2008. The Geography of Trade: Assyrian Colonies in Anatolia c. 1975 1725 BC and the Study of Early Interregional Networks of Exchange, in: Dercksen, J.G. (Ed.), Anatolia and the Jazira during the Old Assyrian Period (Old Assyrian Archives, Studies 3). Nederlands Instituut door het Nabije Osten, Leiden, pp. 87-100.

Barjamovic, G., 2011. A Historical Geography of Anatolia in the Old Assyrian Colony Period. University of Copenhagen/Museum Tusculanum Press, Copenhagen.

Barjamovic, G., in press. Interlocking commercial networks and the infrastructure of trade in western Asia during the Bronze Age, in: Kristiansen, K., Lindkvist, T., Myrdal, J. (Eds.), Trade and Civilization in the Pre-Modern World. Cambridge University Press, Cambridge.

Barjamovic, G., Hertel, T., Larsen, M.T., 2012. Ups and downs at Kanesh. PIHANS Volume 120. Nederlands Instituut voor het Nabije Oosten, Leiden.

Barnett, R.D., 1982. Ancient Ivories in the Middle East and Adjacent Countries. Hebrew University, Jerusalem.

Begemann, F., Schmitt-Strecker, S., 2009. Über das frühe Kupfer Mesopotamiens. Iranica Antiqua 44, 1-45.

Bernabò Brea, L., 1964. Poliochni, citta' preistorica nell'isola di Lemnos, vol.1. L'Erma di Bretschneider, Roma. 
Bernabò Brea, L., 1976. Poliochni, citta' preistorica nell'isola di Lemnos, vol.2. L'Erma di Bretschneider, Roma.

Betancourt, P., 2014. Hagios Charalambos: A Minoan Burial Cave in Crete: I. Excavation and Portable Objects. INSTAP Academic Press, Philadelphia.

Betancourt, P., Muhly, J.D., Ferrence, S.C., 2017. A Gold and Lapis Lazuli Bead from Petras, Crete, in: Maner, Ç., Horowitz, M.T., Gilbert, A.S. (Eds.), Overturning Certainties in Near Eastern Archaeology: A Festschrift in Honor of K. Aslıhan Yener. Brill, Leiden, pp. 67-80.

Bevan, A., 2010. Making and Marking Relationships: Bronze Age Brandings and Mediterranean Commodities, in: Bevan, A., Wengrow, D. (Eds.), Cultures of Commodity Branding. Left Coast Press, Walnut Coast, pp. 35-85.

Biga, G.M., 2014. Inherited Space - Third Millennium Political and Cultural Landscape, in: Cancik-Kirschbaum, E., Brisch, N., Eidem, J. (Eds.), Constituent, Confederate, and Conquered Space: The Emergence of the Mittani State. De Gruyter, Berlin, Boston, pp. 93110.

Bilgi, Ö., 2012. Anadolu'da İnsan Görüntüleri. Klasik Çağ Öncesi. Aygaz Yayınları, Istanbul.

Bittel, K., Naumann, R., Beran, T., Hachmann, A., Kurt, G., 1957. Boğazköy III: Funde aus den Grabungen 1952-1955. G. Mann, Berlin.

Blegen, C.W., Caskey, J.L., Rawson, M., 1951. Troy : the third, fourth and fifth settlements. Excavations conducted by the University of Cincinnati 1932-1938. Princeton University Press, Princeton.

Bobokhyan, A., 2009. Trading implements in early Troy. Anatolian Studies 59, 19-60.

Boehmer, R.M., 1972. Boğazköy-Hattusa VII: Die Kleinfunde von Boğazköy aus den Grabungskampagnen 1931-1939 und 1952-1969. G. Mann, Berlin.

Bourgeois, R., 1992. An approach to Anatolian techniques of ivory carving during the second millennium BC, in: Fitton, J.L. (Ed.), Ivory in Greece and the Eastern Mediterranean from the Bronze Age to the Hellenistic Period. British Museum London, pp. 61-66.

Braidwood, R., Braidwood, L., 1960. Excavations in the plain of Antioch I: the earlier assemblages, phases A-J. Oriental Institute Chicago, Chicago.

Broodbank, C., 2000. An island archaeology of the early Cyclades. Cambridge University Press, New York.

Broodbank, C., 2014. The Making of the Middle Sea. A History of the Mediterranean from the Beginning to the Emergence of the Classical World. Oxford university Press, Oxford.

Çakırlar, C., İkram, S., 2016. 'When elephants battle, the grass suffers.' Power, ivory and the Syrian elephant. Levant 48, 167-183.

Callaway, J.A., 1972. The early bronze age sanctuary at Ai (et-Tell). Quaritch, London.

Carter, T., Grant, S., Kartal, M., Coşkun, A., Özkaya, V., 2013. Networks and Neolithisation: sourcing obsidian from Körtik Tepe (SE Anatolia). Journal of Archaeological Science 40, 556-569. 
Casanova, M., 2000. Le lapis-lazuli de l'Asie centrale à la Syrie au Chalcolithique et à l'âge du Bronze: traits communs et particularités régionales, in: Matthiae, P., Peyronel, L., Pinnock, F. (Eds.), Proceedings of the First International Congress on the Archaeology of the Ancient Near East. Harassowitz, Roma, pp. 171-183.

Casanova, M., 2001. Le lapis-lazuli, la pierre précieuse de l'Orient ancien. Dialogues d'histoire ancienne 27, 149-170.

Caubet, A., 2013. Working ivory in Syria and Anatolia during the Late Bronze-Iron Age, in: Yener, A.K. (Ed.), Across the Border: Late Bronze-Iron Age Relations between Syria and Anatolia. Proceedings of a Symposium held at the Research Center of Anatolian Studies, Koç University, Istanbul. May 31-June 1, 2010. Peeters, Leuven, pp. 449-463.

Caubet, A., Poplin, F., 1992. La place des ivoires d'Ougarit dans la production du Proche Oriént Ancien, in: Fitton, J.L. (Ed.), Ivory in Greece and the Eastern Mediterranean from the Bronze Age to the Hellenistic Period. British Museum London, pp. 91-100.

Cohen, A., 1969. Custom and Politics in Urban Africa: a study of Hausa migrants in Yoruba towns. University of California Press, Berkeley.

Cohen, A., 1971. Cultural strategies in the organization of trading diasporas, in: Meilassoux, C. (Ed.), The development of indigenous trade and markets in West Africa. Oxford University Press, London, pp. 266-281.

Colburn, C.J., 2008. Exotica and the Early Minoan Elite: Eastern Imports in Prepalatial Crete. American Journal of Archaeology 112, 203-224.

Crowfoot Payne, J., 1968. Lapis Lazuli in Early Egypt. Iraq 30, 58-61.

Cusick, J.G., 1998. Historiography of acculturation: An evaluation of concepts and their application in archaeology, in: Cusick, J.G. (Ed.), Studies in culture contact: interaction, culture change, and archaeology. SIU Press, Carbondale, pp. 126-145.

Czichon, R.M., Werner, P., 1998. Tall Munbaqa - Ekalte I. Die bronzezeitlichen Kleinfunde. Mitteilungen der Deutschen Orient-Gesellschaft, Saarbrucken.

Dalley, S., 2002. Mari and Karana: two old Babylonian cities. Gorgias Press, Piscataway, NJ.

Davis, S.J., 1976. Mammal Bones from the Early Bronze Age City of Arad, Northern Negev, Israel: Some Implications Concerning Human Exploitation. Journal of Archaeological Science 3, 153-164.

Dercksen, J.G., 1996. The Old Assyrian Copper Trade in Anatolia. Nederlands HistorischArchaeologisch Instituut, Istanbul.

Dercksen, J.G., 2001. "When we met in Hattuš". Trade according to Old Assyrian Text from Alishar and Boğazköy, in: van Soldt, H.W., Derckesen, J.G., Kouwenberg, N.J.C., Krispijn, T.J.H. (Eds.), Veenhof Anniversary Volume: Studies Presented to Klaas R. Veenhof on the Occasion of His Sixty-fifth Birthday. Nederlands Instituut voor het Nabije Oosten, Leiden, pp. 39-66.

Dercksen, J.G., 2004. Old Assyrian Institutions. Nederlands Instituut voor het Nabije Oosten, Leiden. 
Efe, T., 2007. The theories of the 'Great Caravan Route' between Cilicia and Troy: the Early Bronze Age III period in inland western Anatolia. Anatolian Studies 57, 47-64.

Emerin, K., Jackson, A., McCartney, C., Peltenburg, E., Shortland, A., 2015. Other objects, including personal ornaments and figurines, in: Peltenburg, E. (Ed.), Tell Jerablus Tahtani, Syria, I: Mortuary Practices at an Early Bronze Age Fort on the Euphrates River. Council for British Research in the Levant, London, pp. 172-200.

Emre, K., 1999. Syrian Bottles from the Karum of Kanish, in: Mikasa, H.I.H.P.T. (Ed.), Essays on Ancient Anatolia. Harassowitz, Wiesbaden, pp. 39-50.

Falsone, G., Sconzo, P., 2010. Tell Shiyukh Tahtani. Relazione della campagna di scavo 2010. Retrieved at http://www.unipa.it/falsone/it/TST10_it.pdf [Last accessed 14/10/2017].

Feldman, M., 2006. Diplomacy by Design. University of Chicago Press, Chicago.

Genz, H., 2003. Ritzverzierte Knochenhülsen des dritten Jahrtausends im Ostmittelmeerraum : Eine Studie zu den frühen Kulturverbindungen zwischen Levante und Ägäis Harrassowitz, Wiesbaden.

Genz, H., 2011. Restoring the balance: an Early Bronze Age scale beam from Tell FadousKfarabida, Lebanon. Antiquity 85, 839-850.

Goldman, H., 1956. Excavations at Gözlü Kule, Tarsus: From the Neolithic through the Bronze Age. Princeton University Press, Princeton.

Gosden, C., 2004. Archaeology and Colonialism. Cambridge University Press, Cambridge.

Haas-Lebegyiev, J., Renfrew, C., 2013. The spools from Dhaskalio, in: Renfrew, C., Philaniotou, O., Brodie, N., Gavalas, G., Boyd, M.J. (Eds.), The Settlement at Dhaskalio. McDonald Institute for Archaeological Research, Cambridge, pp. 491-504.

Hafford, W.B., 2005. Hanging in the Balance: Precision Weighing in Antiquity. Expedition 47, 35-37.

Hafford, W.B., 2012. Weighing in Mesopotamia: The Balance Pan Weights from Ur. Akkadica 133, 21-65.

Hawkins, J.D., 1986. Writing in Anatolia: Imported and Indigenous Systems. World Archaeology 17, 363-376.

Helwing, B., 2014. Silver in the early state societies of Greater Mesopotamia, in: Meller, H., Risch, R., Pernicka, E. (Eds.), Metalle der Macht - Frühes Gold und Silber. Metals of powerEarly gold and silver. Tagungen des Landesmuseums für Vorgeschichte Halle, Halle/Saale, pp. 411-422.

Hendrikx, S., Bavay, L., 2002. The relative chronological position of Egyptian Predynastic and Early Dynastic tombs with objects imported from the Near East and the nature of interregional contacts, in: Levy, T.E., van den Brink, E.C.M. (Eds.), Egypt and the Levant. Interrelations from the 4th through the early 3rd Millennium B.C.E. Leicester University Press, London, pp. 58-80.

Herrmann, G., 1968. Lapis Lazuli: The Early Phases of Its Trade. Iraq 30, 21-57. 
Hooijer, D.A., 1978. Report on an Elephant Molar from Ras Shamra-Ugarit. Ugaritica VII, 187-189.

Horejs, B., 2009. Metalworkers at the Çukuriçi Höyük? An Early Bronze Age Mould and a "Near Eastern Weight" from Western Anatolia, in: Kienlin, T., Roberts, B.W. (Eds.), Metals and Society: Studies in honour of Barbara Ottaway. R.Habelt GMBH, Bonn, pp. 358-368.

Horejs, B., 2016. Neue Gewichtssysteme und metallurgischer Aufschwung im frühen 3. Jahrtausend - ein Zufall, in: Bartelheim, M., Horejs, B., Krauss, R. (Eds.), Von Baden bis Troia. Ressourcennutzung, Metallurgie und Wissenstransfer. Eine Jubiläumsschrift für Ernst Pernicka. Leidorf, Rahden/Westfalen, pp. 251-272.

Horejs, B., Milić, B., Ostmann, F., Thanheiser, U., Weninger, B., Galik, A., 2015. The Aegean in the Early 7th Millennium BC: Maritime Networks and Colonization. Journal of World Prehistory 28, 289-330.

Horwitz, L.K., Tchernov, E., 1990. Cultural and Environmental Implications of Hippopotamus Bone Remains in ArchaeologicalContexts in the Levant. Bulletin of the American Schools of Oriental Research 280, 67-76.

Jablonka, P., 2014. Globalisierung im 3. Jahrtausend v. und n. Chr. - Interpretationen archäologisch sichtbarer Kontakte von der Ägäis bis zum Indus von der nordwestlichen Peripherie aus betrachtet. Altorientalische Forschungen 41, 41-62.

Joannès, F., 1996. Routes et voies de communication dans les archives de Mari, in: Durand, J.-M. (Ed.), Amurru 1: Mari, Ebla et les Hourrites, dix ans de travaux. Actes du Colloque international, première partie. Editions Recherche sur les Civilizations, Paris, pp. 323-361.

Karwiese, S., 1990. Šiklu, kitu und stater: der Weg zu einer neuen Metrologie des Altertums, I. Mesopotamien, in: Gyselen, R. (Ed.), Prix, salaires, poids et mesures. Peeters, Paris, pp. 9118.

Kaschau, G., 1999. Lidar Hüyük. Die Keramik Der Mittleren Bronzezeit. P. von Zabern, Mainz am Rhein.

Kayafa, M., Stos-Gale, Z., Gale, N., 2000. The Circulation of Copper in the Early Bronze Age in the mainland Greece: The Lead Isotope Evidence from Lerna, Lithares and Tsoungiza., in: Pare, C.F.E. (Ed.), Metals Make the World Go Round: The Supply and Circulation of Metals in Bronze Age Europe, Oxford, pp. 39-55.

Kenna, V.E.G., 1970. The Evidence of the Glyptic from Poliochni in the Island of Lemnos. Istanbuler Mitteilungen 19/20, 109-112.

Kepinski, C., 2005. Tilbeshar - A Bronze Age City in the Sajur Valley (Southeast Anatolia). Anatolica 31, 145-159.

Knapp, A.B., 2013. The Archaeology of Cyprus: From Earliest Prehistory through the Bronze Age. Cambridge University Press, Cambridge.

Kontani, R., 1995. Relations between Kültepe and Northern Syria during the third Millenium BC. Bulletin of the Ancient Orient Museum 16, 109-142. 
Kontani, R., 2010. Observations on "Syrian Bottle" Shaped Imported Vessels from Kültepe, in: Kulakoğlu, F., Kangal, S. (Eds.), Anatolia's Prologue, Kültepe Kanesh Karum, Assyrians in Istanbul. Kayseri Metropolitan Municipality, Kayseri, pp. 52-55.

Kool, J., 2012. The Old Assyrian Trade Network from an Archaeological Perspective. Unpublished BA dissertation, Leiden University.

Korfmann, M.O., 2001. Troia als Drehscheibe des Handels im 2. und 3. vorchristlichen Jahrtausend: Erkenntnisse zur Troianischen Hochkultur und zur Maritimen Troia-Kultur, in: Korfmann, M.O. (Ed.), Traum und Wirklichkeit: Troia. Theiss, Stuttgart, pp. 355-368.

Krzyszkowska, O., 1988. Ivory in the Aegean Bronze Age: Elephant Tusk or Hippopotamus Ivory? The Annual of the British School at Athens 83, 209-234.

Krzyszkowska, O., 2005. Aegean Seals: An Introduction. Institute of Classical Studies, School of Advanced Study, London.

Krzyszkowska, O., Morkot, R., 2000. Ivory and Related Materials, in: Nicholsob, P.T., Shaw, I. (Eds.), Ancient Egyptian Materials and Technology. Cambridge University Press, Cambridge, pp. 320-331.

Kühne, H., 1976. Die Keramik von Tell Chuera und ihre Beziehungen zu Funden aus Syrien Palästina, der Türkei und dem Iraq. Gebr. Mann, Berlin.

Kuhrt, A., 1995. The Ancient Near East, c. 3000-330 BC. Routledge, London and New York.

Kulakoğlu, F., Barjamovic, G., 2017. Movement, Resources, Interaction. Proceedings of the 2nd Kültepe International Meeting, Kültepe, 26-30 July 2015, Subartu XXXIX. Brepols, Turnhout.

Kulakoğlu, F., Emre, K., Kontani, R., Ezer, S., Öztürk, G., 2013. Kültepe-Kaniş, Turkey: Preliminary Report on the 2012 Excavations. Bulletin of the Okayama Orient Museum 27, 43-50.

Kulakoğlu, F., Kangal, S., 2010. Anatolia's prologue : Kultepe, Kanesh, Karum: Assyrians in Istanbul. Kayseri Büyükşehir Belediyesi, Kayseri.

Lafrenz, K.A., 2004. Tracing the source of the elephant and hippopotamus ivory from the 14th century B.C. Uluburun shipwreck: The archaeological, historical, and isotopic evidence. Unpublished MA dissertation, University of South Florida.

Lamb, W., 1936. Excavations at Thermi in Lesbos. Cambridge University Press, Cambridge.

Lamberg-Karlovski, C.C., 1972. Trade Mechanisms in Indus-Mesopotamian Interrelations. Journal of the American Oriental Society 92, 222-230.

Lambert, M., 1953. Textes commerciaux de Lagash. Revue d'Assyriologie et d'archéologie orientale 47, 57-69.

Larsen, M.T., 1976. The old Assyrian city-state and its colonies. Akademisk Forlag, Copenhagen. 
Larsen, M.T., 1987. Commercial networks in the ancient Near East, in: Rowlands, M.J., Larsen, M.T., Kristiansen, K. (Eds.), Centre and periphery in the ancient world. Cambridge University Press, Cambridge, pp. 47-56.

Larsen, M.T., 2015. Ancient Kanesh: A Merchant Colony in Bronze Age Anatolia. Cambridge University Press, Cambridge.

Law, R.W., 2008. Inter-regional interaction and urbanism in the ancient Indus Valley: a geologic provenience study of Harappa's rock and mineral assemblage. Unpublished PhD dissertation, University of Wisconsin.

Law, R.W., 2014. Evaluating potential lapis lazuli sources for ancient South Asia using sulphure isotope analysis, in: Lamberg-Karlovski, C.C., Genito, B., Cerasetti, B. (Eds.), "My life is like the Summer Rose": Maurizio Tosi e l'Archeologia come modo di vivere. Papers in honour of Maurizio Tosi for his 70th birthday. Archaeopress, Oxford, pp. 419-429.

Legarra Herrero, B., 2014. Mortuary Behavior and Social Trajectories in Pre- and Protopalatial Crete. INSTAP Academic Press, Philadelphia.

Ludvik, G., Kenoyer, J.M., Pieniążek, M., Aylward, W., 2015. New perspectives on stone bead technology at Bronze Age Troy. Anatolian Studies 65, 1-18.

Marchetti, N., Nigro, L., 1997. Cultic Activities in the Sacred Area of Ishtar at Ebla during the Old Syrian Period: The "Favissae" F. 5327 and F. 5238. Journal of Cuneiform Studies 49, $1-44$.

Massa, M., 2016. Networks before Empires: cultural transfers in Anatolia during the Early Bronze Age. Unpublished PhD dissertation, University College London.

Massa, M., Palmisano, A., in press. Commercial landscapes of long-distance contacts in Western Asia, c. 3200 - 1600 BC: perspectives from material culture. Journal of Open Archaeology Data 6.

Massa, M., Şahoğlu, V., 2015. The 4.2ka climatic event in west and central Anatolia: combining palaeoclimatic proxies and archaeological data, in: Meller, H., Risch, R., Jung, R., Arz, R.W. (Eds.), 2200 BC - A climatic breakdown as a cause for the collapse of the Old World? . Landesmuseums für Vorgeschichte Halle, Halle, pp. 61-78.

Massa, M., Tuna, Y., in press. A clay stopper from Boz Höyük (Afyon) in the context of the western and central Anatolian Early Bronze Age sealing practices. Anatolian Studies 68.

Mazzoni, S., 1980. Sigilli a stampo protostorici di Mardikh I. Studi Eblaiti 4/5, 53-80.

Mederos, A., Lamberg-Karlovsky, C.C., 2004. Weight Systems and Trade Networks in the Old World (2500-1000 BC), in: Hudson, M., Wunsch, C. (Eds.), Creating economic order: record-keeping, standardisation, and teh development of accounting in the ancient Near East. CDL, Bethesda.

Michel, C., 2001. Correspondance des marchands de Kaniš au début du IIe millenaire a.v. J.C. Édition du Cerf, Paris.

Miglus, P., Strommenger, E., 2007. Ausgrabungen in Tall Bi'a / Tuttul. Band VII: Der Palast A. Harrassowitz, Wiesbaden. 
Moorey, P.R.S., 1994. Ancient mesopotamian materials and industries: The archaeological evidence. Clarendon Press, Oxford.

Nezafati, N., Pernicka, E., 2012. Early Silver Production in Iran. Iranian Archaeology 3, 3745.

Nissen, H.J., Damerow, P., Englund, P.K., 2004. Informationsverarbeitung vor 5000 Jahren. Frühe Schrift und Techniken der Wirtschaftsverwaltung im alten Vorderen Orient. Franzbecker, Hildesheim.

Oates, D., Oates, J., MacDonald, H., 2001. Excavations at Tell Brak: Nagar in the third millennium BC. McDonald Institute, Cambridge.

Oded, B., 1992. War, Peace, and Empire: Justifications for War in Assyrian Royal Inscriptions. Dr. Ludwig Reichert Verlag, Wiesbaden.

Oppenheim, A.L., 1954. The Seafaring Merchants of Ur. Journal of the American Oriental Society 74, 6-17.

Orthmann, W., Rova, E., 1991. Ausgrabungen in Wreide 2 Gräber des 3. Jahrtausends v.Chr. im Syrischen Euphrattal. Saarbrücker Druckerei, Bonn.

Özgüç, T., 1963. Early Anatolian Archaeology in the Light of recent Research. Anadolu 7, 121.

Özgüç, T., 1986a. Kültepe Kaniş 2: Eski Yakındoğu'nun Ticaret Merkezinde Yeni Araştırmalar. Türk Tarih Kurumu, Ankara.

Özgüç, T., 1986b. New Observations on the Relationship of Kültepe with Southeast Anatolia and North Syria during the Third Millennium B.C., in: Vorys Canby, J., Porada, E., Sismondo Ridgway, B., Stech, T. (Eds.), Ancient Anatolia. Aspects of Change and Cultural Development. Essays in Honor of Machteld J. Mellink. University of Wisconsin Press, Wisconsin, pp. 31-47.

Özgüç, T., Özgüç, N., 1953. Ausgrabungen in Kültepe. Bericht über die im Auftrage der Türkischen Historischen Gesellschaft, 1949 durchgefürten Ausgrabungen. Türk Tarih Kurumu, Ankara.

Pakkanen, J., 2011. Aegean Bronze Age Weights, Chaînes Opératoires and the Detecting of Patterns through Statistical Analyses, in: Brysbaert, A. (Ed.), Tracing Prehistoric Social Networks through Technology: a diachronic perspective on the Aegean. Routledge, New York, pp. 143-166.

Palmisano, A., 2015. Spatial Approaches to the Political and Commercial Landscape of the Old Assyrian Colony Period. Unpublished PhD dissertation, University College London.

Palmisano, A., Altaweel, M., 2015. Simulating Past Human Landscapes: Models of Settlement Hierarchy in Central Anatolia during the Old Assyrian Colony Period, in: Kulakoğlu, F., Michel, C. (Eds.), Proceedings of the 1st Kültepe International Meeting. Kültepe, September 19-23, 2013. Studies Dedicated to Kutlu Emre. Brepols, Turnhout, pp. 131-146.

Parise, N., 1991. Dai pesi egei per la lana alla mina di Dudu. Quaderni Ticinesi di Numismatica e Antichita' Classiche 20, 13-16. 
Parrot, A., 1959. Mission Archeologique de Mari III: Les Temples d'Ishtarat et de NinniZaza. Librairie orientaliste P. Geuthner, Paris.

Petruso, K., 1978. System of Weight in the Bronze Age Aegean. Unpublished PhD dissertation, Indiana University.

Petruso, K., 1981. Early Weights and Weighing in Egypt and the Indus Valley. Bulletin of the Museum of Fine Arts, Boston 79, 44-51.

Pettinato, G., 1974. Il commercio con l'estero della Mesopotamia meridionale nel III mill. av.C. alla luce delle fonti letterarie e lessicali sumeriche. Mesopotamia VII, 43-166.

Peyronel, L., 2012. Resource exploitation and handicraft activities at Tell Mardikh/Ebla (Syria) during the Early and Middle Bronze Ages, in: Curtis, J., Fletcher, A., Glatz, C., Matthews, R., Seymour, M., Simpson, J., Taylor, H. (Eds.), Proceedings of the 7th ICAANE Conference held in London in 2010. Harassowitz, Wiesbaden, pp. 475-496.

Peyronel, L., 2014. Between Archaic Market and Gift Exchange: the Role of Silver in the Embedded Economies of the Ancient Near East During the Bronze Age, in: Carlà, F., Gori, M. (Eds.), Gift Giving and the 'Embedded' Economies in the Ancient World. Universitätsverlag Winter, Heidelberg, pp. 355-376.

Peyronel, L., 2015. Tra il Mare Superiore e Mare Inferiore, vendendo da Oriente. Riflessioni sugli scambi a lunga distanza di materiali preziosi nel Vicino Oriente durante il Bronzo Antico, in: Asero, E. (Ed.), Strade di uomini e di idee. La circolazione materiale e interculturale tra Mediterraneo orientale e Vicino Oriente antico. Atti del Convengo (Milano, 8-9 luglio). Arachne, Milano, pp. 65-88.

Peyronel, L., 2016. Bone and ivory manufacturing at Ebla (Syria) during the Early and Middle Bronze Age (c.2500-1600 BC). Levant 48, 1-13.

Pfälzner, P., 2013. The Elephant Hunters of Bronze Age Syria, in: Aruz, J., Graff, S.B., Rakic, E. (Eds.), Cultures in Contact: From Mesopotamia to the Mediterranean in the Second Millennium BC. The Metropolitan Museum of Art, New York, pp. 112-131.

Philip, G., Clogg, P.W., Dungworth, D., 2003. Copper Metallurgy in the Jordan Valley from the Third to the First Millennia BC: Chemical, Metallographic and Lead Isotope Analyses of Artefacts from Pella. Levant 35, 71-100.

Platon, N., Pini, I., Salies, G., 1977. Iraklion, Archäologisches Museum. Teil 2. Die Siegel der Altpalastzeit. Heidelberg University, Berlin.

Poursat, J.C., 1992. Ivory relief carving in Minoan Crete (2000-1450 BC), in: Fitton, J.L. (Ed.), Ivory in Greece and the Eastern Mediterranean from the Bronze Age to the Hellenistic Period. British Museum London, pp. 3-5.

Powell, M.A., 1999. Monies, Motives and Methods in Babylonian Economics., in: Dercksen, J.G. (Ed.), Trade and finance in ancient Mesopotamia. Nederlands HistorischArchaeologische Instituut, Leiden, pp. 5-23.

Pulak, C., 2000. The balance weights from the Late Bronze Age shipwreck at Uluburun, in: Pare, C.F.E. (Ed.), Metals Make the World Go Round: The Supply and Circulation of Metals in Bronze Age Europe. Oxbow, Oxford, pp. 247-266. 
Rahmstorf, L., 2003. The identification of Early Helladic weights and their wider implications, in: Polinger, K., Laffineur, R. (Eds.), Metron: Measuring the Aegean Bronze Age, Proceedings of the 9th International Aegean Conference, New Haven, Yale University, 18-21 April 2002. University of Liege, Liege, pp. 293-299.

Rahmstorf, L., 2006a. In search of the earliest balance weights, scales and weighing systems from the Eastern Mediterranean, the Near and Middle East, in: Alberti, M.E., Ascalone, E., Peyronel, L. (Eds.), Weights in context. Bronze Age weighing systems of Eastern Mediterranean: chronology, typology, material and archaeological contexts. Proceedings of the International Colloquium, Rome 22-24 November 2004. Istituto Italiano di Numismatica, Roma, pp. 9-45.

Rahmstorf, L., 2006b. Zur Ausbreitung vorderasiatischer Innovationen in die friihbronzezeitliche Agais. Praehistorische Zeitschrift für Assyriologie und Vorderasiatische Archäologie 81, 49-96.

Rahmstorf, L., 2009. Early Bronze Age balance weights from Tarsus, Alişar Höyük and other sites. Araştırma Sonuçları Toplantısı 26, 201-210.

Rahmstorf, L., 2010. The concept of weighing during the Bronze Age in the Aegean, Near East and Europe, in: Morley, I., Renfrew, C. (Eds.), The archaeology of measurement: comprehending Heaven, Earth and Time in ancient societies. CUP, Cambridge, pp. 89-105.

Rahmstorf, L., 2011. Maß für Maß: Indikatoren für Kulturkontakte im 3. Jahrtausend, in: Horst, K. (Ed.), Kykladen: Lebenswelten einer frügriechischen Kultur. Badischen Landesmuseum, Karlsruhe, pp. 144-153.

Rahmstorf, L., 2016. Emerging Economic Complexity in the Aegean and Western Anatolia during Earlier Third Millennium BC, in: Molloy, B.P.C. (Ed.), Of Odysseys and Oddities: Scales and modes of interaction between prehistoric Aegean societies and their neighbours. Oxbow, Oxford, pp. 225-276.

Ratnagar, S., 1981. Encounters: The Westerly Trade of the Harappan Civilization. Oxford University Press, Delhi.

Re, A., Lo Giudice, A., Angelici, D., Calusi, S., Giuntini, L., Massi, M., Pratesi, G., 2011. Lapis lazuli provenance study by means of micro-PIXE. Nuclear Instruments and Methods in Physics Research B 269, 2373-2377.

Rehak, P., Younger, J.G., 1998. International styles in ivory carving in the Bronze Age, in: Cline, E.H., Harris-Cline, D. (Eds.), The Aegean and the Orient in the Second Millennium. Proceedings of the 50th Anniversary Symposium, Cincinnati, 18-20 April 1997. Université de Liège, Liège, pp. 229-255.

Renfrew, C., 1975. Trade as Action at a Distance: Questions of Integration and Communication, in: Sabloff, J.A., Lamberg-Karlovsky, C.C. (Eds.), Ancient Civilization and Trade. University of New Mexico Press, Albuquerque, pp. 3-59.

Ross, J.C., 1999. The golden ruler : precious metals and political development in the third millennium B.C. Near East. Unpublished PhD dissertation, University of California. 
Rowan, Y.M., 2013. The southern Levant (Cisjordan) during the Chalcolithic period, in: Killebrew, A., Steiner, M. (Eds.), Oxford Handbook of the Archaeology of the Levant. Oxford University Press, Oxford, pp. 223-236.

Rowlands, M.J., 1998. Centre and periphery: a review of a concept, in: Kristiansen, K., Rowlands, M.J. (Eds.), Social Transformations in Archaeology. Routledge, London.

Şahoğlu, V., 2005. The Anatolian Trade Network and the Izmir Region during the Early Bronze Age. Oxford Journal of Archaeology 24, 339-360.

Şahoğlu, V., 2012. Çeşme-Bağlararası, in: Bingöl, O., Öztan, A., Taşkıran, H. (Eds.), Dil ve Tarih-Coğrafya Fakültesi 75.Yı1 Armağanı: Arkeoloji Bölümü Tarihçesi ve Kazıları (19362011). Ankara Üniversitesi Basimevi, Ankara, pp. 83-90.

Sar1, D., 2011. Evolution Culturelle et Politique de l'Anatolie de l'Ouest au Bronze Ancien et au Bronze Moyen. Unpublished PhD Université de Strasbourg and Istanbul Üniversitesi.

Scandone-Matthiae, G., 2002. Gli avori egittizzanti dal palazzo settentrionale. Universita' La Sapienza, Roma.

Scandone-Matthiae, G., 2006. Nuovi frammenti di avori egittizzanti di Ebla, in: E., C., I., H., H., H., D., M., A., S. (Eds.), Timelines: studies in honour of Manfred Bietak, vol. III. Peeters, Leuven, pp. 81-86.

Schachner, Ş., Schachner, A., 1995. Eine Syrische Flasche aus Fara. Mitteilungen der Deutschen Orient-Gesellschaft zu Berlin 127.

Schliemann, H., 1881. Ilios: Stadt und Land der Trojaner. Forschungen und Entdeckungen in der Troas und besonders auf der Baustelle von Troja. Brockhaus, Leipzig.

Schwartz, G.M., Curvers, H.H., Dunham, S.S., Stuart, B., Weber, J.A., 2006. A ThirdMillennium B.C. Elite Mortuary Complex at Umm El-Marra, Syria: 2002 and 2004Excavations. American Journal of Archaeology 110, 603-641.

Schwartz, G.M., Curvers, H.H., Dunham, S.S., Weber, J.A., 2012. From Urban Origins to Imperial Integration in Western Syria: Umm el-Marra 2006, 2008. American Journal of Archaeology 116, 157-193.

Sheldon, D.G., 1971. A Study of Mesopotamian Ivories pre-1000 BC. Unpublished PhD, Bryn Mawr College.

Sowada, K., 2009. Egypt in the Eastern Mediterranean During the Old Kingdom: An Archaeological Perspective. Academic Press Fribourg, Vandenhoeck \& Ruprecht Göttingen, Fribourg.

Stein, G., 2005. The Political Economy of Mesopotamian Colonial Encounters, in: Stein, G. (Ed.), The Archaeology of Colonial Encounters: comparative perspectives. School of American Research Press, Santa Fe, pp. 143-172.

Stein, G., 2008. A theoretical model for political economy and social identity in the Old Assyrian colonies of Anatolia. TÜBA-AR XI, 25-40.

Stos-Gale, Z., Gale, N., 2010. Bronze Age metal artefacts found on Cyprus - metal from Anatolia and the Western Mediterranean. Trabajos de Prehistoria 67, 389-403. 
Strommenger, E., Kohlmeyer, K., 1998. Tall Bi'a/Tuttul I: Die Altorientalische Bestattungen. Saarbrücken Druckerei und Verlag, Saarbrücken.

Tonussi, M., 2007. Dall'Eufrate allo Scamandro: contatti e scambi nel terzo millennio a. C. Il Poligrafo, Padova.

Tosi, M., 1974. The Lapis lazuli Trade across the Iranian Plateau in the 3rd Millennium B.C., in: Forte, A. (Ed.), Gururajamanjarika: Studi in onore di Giuseppe Tucci, vol. 1. Istituto Universitario Orientale, Napoli, pp. 3-22.

Tosi, M., Vidale, M., 1990. 4th Millennium BC Lapis Lazuli Working at Mehrgarh, Pakistan. Paléorient 16, 89-99.

Türkteki, M., 2010. Batı ve Orta Anadolu'da Çark Yapımı Çanak Çömleğin Ortaya Çıkışı ve Yayılımı. Unpublished PhD Dissertation, Istanbul University.

Türkteki, M., 2013. The First Use of Wheel-Made Pottery and its Distribution in Western and Central Anatolia, in: Bombardieri, L., D’Agostino, A., Guarducci, G., Orsi, V., Valentini, S. (Eds.), SOMA 2012: Identity and Connectivity. Proceedings of the 16th Symposium on Mediterranean Archaeology, Florence, Italy, 1-3 March 2012. Archaeopress, Oxford, pp. 193-200.

Unger, E., 1918. Katalog der babylonischen und assyrischen Sammlung. III, 1. Gewichte und gewichtsähnliche Stücke. Ahmed Ihsan \& Co., Istanbul.

van den Hout, T., 2010. The Rise and Fall of Cuneiform Script in Hittite Anatolia, in: Woods, C., Teeter, E., Emberling, G. (Eds.), Visible Language. Inventions of Writing in the Ancient Middle East and Beyond. Oriental Institute of Chicago, Chicago, pp. 99-108.

Veenhof, K.R., 1972. Aspects of Old Assyrian Trade and its Terminology. Brill, Leiden.

Veenhof, K.R., Eidem, J., 2008. Mesopotamia, The Old Assyrian Period. Academic Press Fribourg, Fribourg.

Villard, P., 1986. Un roi de Mari à Ugarit. Ugarit-Forschungen 18, 387-412.

Waal, W., 2012. Writing in Anatolia: The Origins of the Anatolian Hieroglyphs and the Introductions of the Cuneiform Script. Altorientalische Forschungen 39, 287-315.

Wallerstein, I.M., 1974. The Modern World-System: Capitalist Agriculture and the Origins of the European World-Economy in the Sixteenth Century. Academic Press, New York/London.

Watrous, L.V., 1998. Egypt and Crete in the Early Middle Bronze Age: a Case of Trade and Cultural Diffusion, in: Cline, E.H., Harris-Cline, D. (Eds.), The Aegean and the Orient in the Second Millennium. Proceedings of the 50th Anniversary Symposium, Cincinnati, 18-20 April 1997. Université de Liège, Liège, pp. 19-27.

Webb, J.M., Frankel, D., Stos-Gale, Z., Gale, N., 2006. Early Bronze Age metal trade in the eastern Mediterranean. New compositional and lead isotope evidence from Cyprus. Oxford Journal of Archaeology 25, 261-288.

Weingarten, J., 1990. The Sealing Structure of Karahöyük and Some Administrative Links with Phaistos and Crete. Oriens Antiquus XXIX, 63-95. 
Wiener, M.H., 2013. "Minding the Gap": Gaps, Destructions, and Migrations in the Early Bronze Age Aegean. Causes and Consequences. American Journal of Archaeology 117, 581592.

Wiener, M.H., 2014. The interaction of climate change and agency in the collapse of civilizations ca 2300-2000 BC. Radiocarbon 56, S1-S16.

Wilkinson, T.C., 2014. Tying the threads of Eurasia: Trans-regional routes and material flows in Transcaucasia, eastern Anatolia and western central Asia, c. 3000-1500 BC. Sidestone Press, Leiden.

Woolley, C.L., 1934. Ur Excavations II: The Royal Cemetery. British Museum, London.

Woolley, C.L., 1948. Excavations at Atchana-Alalakh, 1939. The Antiquaries Journal 28, 119.

Yener, A.K., 2007. The Anatolian Middle Bronze Age Kingdoms and Alalakh: Mukish, Kanesh and Trade. Anatolian Studies 57, 151-160.

Yener, A.K., 2010. Tell Atchana, Ancient Alalakh. The 2003-2004 Excavations Seasons. Koç University Press, Istanbul.

Yener, A.K., Sayre, E.V., Joel, E.C., Özbal, H., Barnes, I.L., Brill, R.H., 1991. Stable Lead Isotope Studies of Central Taurus Ore Sources and Related Artifacts from Eastern Mediterranean Chalcolithic and Bronze Age Sites. Journal of Archaeological Science 18, 541-577.

Zeyrek, T.H., Kızıltan, Z., 2005. İstanbul Arkeoloji Müzeleri'nden Seçilmiş Mezopotamya Ağırlıkları. Anadolu Araştırmaları 18, 15-65.

Zimmermann, T., 2005. Perfumes and Policies - A ,Syrian Bottle' from Kinet Höyük and Anatolian Trade Patterns in the Advanced Third Millennium BC. Anatolica 31, 161-169.

Zimmermann, T., 2006. Bottles and netbags: some additional notes on the article about "Syrian bottles" in Anatolica 31, 2005. Anatolica 32, 229-231.

Zöldföldi, J., Richter, S., Kasztovszky, Z., Mihali, J., 2006. Where does lapis lazuli come from? Non-destructive provenance analysis by PGAA, in: Pérez-Arantegui, J. (Ed.), Proceedings of the 34th International Symposium on Archaeometry, Zaragoza 3-7 May 2004. Istitucion Fernando el Catolico, Zaragoza, pp. 353-361. 